\title{
UROCZYSTOŚCI PIĘĆSETLECIA \\ KANONIZACJI ŚW. STANISŁAWA W KRAKOWIE W R. 1753 OKIEM HISTORYKA SZTUKI*
}

W roku 1840 kanonik katedry krakowskiej ksiądz Mateusz Gładyszewicz uczestniczył w uroczystościach ogłoszenia kultu norbertanki z Krakowa, siostry Bronisławy. Wydarzenie to wywarło na nim niezatarte wrażenie, czemu dał wyraz pięć lat później w wydanym przez siebie Żywocie biskupa krakowskiego Prandoty. Opisując w nim krakowskie uroczystości związane z kanonizacją św. Stanisława odwołał się do własnych przeżyć: „Jako była w ówczas wszystkich słowiańskich plemion i obcych rodaków przy owym świętym obrzędzie przytomnych radość, jakie rozrzewnienie; to trudno opisać. Ten tylko może to sobie wyobrazić, kto kiedy miał sposobność przy podobnym obrzędzie się znajdować, a mianowicie kto był w Krakowie przy uroczystym wprowadzeniu czci B. Bronisławy. Wprawdzie ten za dni naszych drogi sercom naszym obrządek, ani co do wspaniałości, ani co do mnogości ludu nie może się równać z kanonizacyą ś. Jana Kantego, a tem mniej z kanonizacyą ś. Stanisława, ale przecież kto był w Krakowie w dniu drugim Września 1840 roku, a słyszał jak przed godziną trzecią po południu na wysokiej wieży Wawelu wspaniały Zygmunt, a za nim wszystkie po wszystkich świątyniach krakowskich dzwony zabrzmiały pierwsze święto B. Bronisławy zwiastując; kto widział jak pobożny orszak kilkunastu tysięcy ludu po ulicach tego starożytnego grodu wspaniale przybranych z kościoła

" Prezentowany tekst powstał w czasie, gdy byłem stypendystą Fundacji na Rzecz Nauki Polskiej. Wsparcie finansowe tej Instytucji umożliwiło mi trzymiesięczny pobyt w Monachium, za co jestem jej niezmiernie wdzięczny. Za pomoc w dotarciu do literatury przedmiotu jestem też winien wdzięczność Pani Urszuli Pütz z Muzeum Diecezjalnego w Paderborn. Za przyjacielską pomoc i merytoryczne konsultacje dziękuję Krzysztofowi J. Czyżewskiemu, Andrzejowi Betlejowi i Piotrowi Krasnemu. 
księży Dominikanów ku murom klasztoru zwierzynieckiego, z świętymi godłami wśród pieśni świętych i modlitw postępowal; a potem jak święte szczątki Bronisławy na ołtarzu wzniesiono; a potem jak hymn dziękczynny Bogu w świętych swych cudownemu $\mathrm{z}$ tysięcznych piersi dobyty odbił się o niebios sklepienia; kto to widział i słyszał, a serce jego nie uczuło osobnego jakiegoś nigdy kiedyindziej niedoznanego wzruszenia, a z oczu jego nie trysnęy łzy tem słodkiem, tem boskiem wzruszeniem wyciśnione; ten nigdy wzniosłych, świętych, niebiańskich prawego chrześcianina uczuć nie doznał, ten twardym głazem być musiał"1. Mocno egzaltowany opis historyka-dyletanta $\mathrm{z}$ w. XIX może być bardzo pouczający. Po pierwsze zwraca naszą uwagę na wciąż nie docenianą przez naukę w Polsce problematykę uroczystości. Po drugie przypomina, że wielkie wydarzenia religijne, takie jak kanonizacja św. Stanisława czy św. Jana Kantego, były w Krakowie pamiętane. W czasie zaborów w sposób szczególny, jawiły się bowiem jako przejawy świetności narodu, chwile, gdy o Polsce głośno było w całym chrześcijańskim świecie. Po trzecie wreszcie przywołuje, jakże ważną w badaniach historycznych, kwestię wyobraźni. Uroczystości towarzyszące kanonizacji św. Stanisława w Asyżu w r. 1253, a później w Krakowie w r. 1254 możemy sobie co najwyżej - tak jak kanonik Gładyszewicz - wyobrazić ${ }^{2}$. Prawie nic nie wiemy też o kolejnych rocznicach tych doniosłych wydarzeń. Dopiero w r. 1753 w aktach krakowskiej kapituły katedralnej opisano szczegółowo wydarzenia związane z pięćsetną rocznicą kanonizacji.

Badania Józefa Lepiarczyka i ks. Bolesława Przybyszewskiego dowiodły, że w latach 1745-1753 w katedrze krakowskiej prowadzono szeroko zakrojone prace architektoniczne, które stanowiły część przygotowań do uroczystości rocznicowych ${ }^{3}$. Według tych autorów wprowadzenie zespołu nowych ołtarzy z obrazami świętych patronów Polski i przesunięcie grobowca króla Władysława Jagiełły „łączyło się z przygotowaniami kapituły do uroczystego obchodu pięćsetnej rocznicy kanonizacji św. Stanisława biskupa, przypadającej na rok $1753^{\prime 4}$. Jak wiadomo, we wspomnianym okresie wzniesiono sześć ołtarzy za-

${ }^{1}$ M. Gładys z e w i c z, Żywot błogostawionego Prandoty z Białaczewa, biskupa krakowskiego, Kraków 1845, s. 33-34.

${ }^{2} \mathrm{O}$ zagadnieniach tych piszę w: M. W a 1 c z a k, Kanonizacja św. Stanisława jako temat historyczny w sztuce Krakowa, „Studia Waweliana” XI (2002), w druku.

${ }^{3}$ Przykładem kompleksowej barokizacji kościoła w zwiazku z uroczystościami jubileuszowymi może służyć katedra we Freising. W r. 1724 świętowano uroczyście tysiąclecie diecezji i w zwiazku z tym, ksiązę biskup Johann Franz Eckher (1696-1727) dokonał kompleksowego przekształcenia swojego kościoła; U. G o t z, Kunst in Freising unter Fürstbischof Johann Franz Eckher 1696-1727. Ausdruckformen geistlicher Herrschaft (Sammelblatt des Historischen Vereins Freising, Bd. 33, Hrsg. H. Glaser), München-Zürich 1992, szczeg. s. 242-278.

${ }^{4}$ J. Le piarczyk, B. Przyby s zew ski, Katedra na Wawelu w wieku XVIII, [w:] Sztuka baroku. Materiaty sesji naukowej ku czci śp. Profesorów Adama Bochnaka i Józefa Le- 
projektowanych przypuszczalnie przez Franciszka Placidiego. Jest on zapewne tożsamy $\mathrm{z}$ anonimowym architektem, któremu kapituła katedralna zapłaciła w maju 1747 r. za ,abrysy na ołtarze y na abryski”. Jako pierwszy ustawiono w ambicie kościoła ołtarz św. Wacława, ufundowany przez biskupa przemyskiego Wacława Hieronima Sierakowskiego. Drugim był ołtarz w odnawianej równocześnie kaplicy Matki Boskiej Śnieżnej (biskupa Maciejowskiego), ufundowany w r. 1752 przez księdza Michała Wodzickiego. W tym samym roku usunięto stare ołtarze stojące przy filarach międzynawowych katedry i ustawiono w ich miejsce nowe, udekorowane namalowanymi przez Tadeusza KuntzeKonicza wizerunkami św. św. Michała, Floriana, Wojciecha i Kazimierza. Powyżej obrazów na ołtarzach tych znalazły się jeszcze mniejsze rzeźbione przedstawienia polskich błogosławionych. I tak obok Floriana umieszczono Salomeę, a obok Kazimierza Kingę ${ }^{6}$. W ten sposób we wnętrzu kościoła powstał zespół jednorodnych stylowo ołtarzy poświęconych świętym patronom kraju i Krakowa. Co ciekawe, poczesne miejsce znalazł wśród nich ołtarz św. Michała, konsekrowany na nowo pomiędzy r. 1766 a 1769 pod wezwaniem bł. Wincentego Kadłubka . Zapewne to pierwsze wezwanie związane było z miejscem męczeńskiej śmierci św. Stanisława „na Skałce” i uzupełniało program liturgiczny przygotowywany pod katem rocznicy ${ }^{8}$. $Z$ czasem straciło swoje znaczenie i zostało zmienione. Assumpt do tej zamiany dała oczywiście beatyfikacja Wincentego Kadłubka doprowadzona do szczęśliwego końca w r. 1764 i uczczona wspaniałą uroczystością w Jędrzejowie w r. $1765^{9}$. Powyżej wizerunku nowego błogosławionego w ołtarzu umieszczono jeszcze przedstawienie Jana z Kęt, ka-

piarczyka zorganizowanej przez Krakowski Oddział Stowarzyszenia Historyków Sztuki i Instytut Historii Sztuki UJ, Kraków, 8-9 czerwca 1990 roku, Kraków 1991, s. 26.

${ }^{5}$ Fabrica Ecclesiae Cracoviensis. Materiaty źródlowe do dziejów katedry krakowskiej $w$ XVIII wieku z archiwów kapitulnych i kurialnych krakowskich, wybór i opracowanie B. Przybyszewski, Kraków 1993 (Źródła do dziejów Wawelu, t. 14, cz. 1), no 175, s. 80; L e p i a r c z y k, Przybys zew ski, dz. cyt., s. 25.

${ }^{6}$ Wygląd ołtarzy podaje spisany w początkach w. XIX Opis kościoła katedralnego krakowskiego $i$ jego osobliwości, zachowany w Archiwum Krakowskiej Kapituły Metropolitalnej na Wawelu; wg J. U r b a n, Katedra na Wawelu (1795-1918), Kraków 2000, s. 23. Wedle tego opisu w ołtarzu św. Wojciecha znajdował się wizerunek św. Teresy. Dlaczego umieszczono tam tę akurat świętą trudno powiedzieć.

${ }^{7}$ Le pi ar c zy k, Pr zy by s zew ski, dz. cyt., s. 26, przyp. 65.

${ }^{8} \mathrm{O}$ zagadnieniu tym wspominałem już w tekście: M. Walczak, Uwagi o artystycznych przejawach kultu św. Jana z Kęt na ziemiach wschodnich dawnej Rzeczypospolitej, "Przegląd Wschodni" 22 (1999/2000), s. 341, przyp. 31.

${ }^{9}$ J. S z y mań s k i, Wincenty, [w:] Hagiografia Polska. Stownik bio-bibliograficzny, red. R. Gustaw, t. II, Poznań-Warszawa-Lublin 1972, s. 529; D. O 1 s z e w s k i, Kult bt. Wincentego Kadtubka w Jędrzejowie, [w:] Cystersi w Polsce. W 850-lecie fundacji opactwa jędrzejowskiego, red. D. Olszewski, Kielce 1990, s. 155. 
nonizowanego w r. 1767. Warto przypomnieć, że w latach 1759-1760 w ambicie wystawiono jeszcze ołtarze ku czci św. Józefa (z fundacji kanonika Józefa Rogalli) i św. Jacka (z fundacji archiprezbitera mariackiego Jacka Augustyna Łopackiego) ${ }^{10}$. Podobnie jak w przypadku pierwszej fundacji Sierakowskiego święci patronowie ołtarzy byli równocześnie patronami darczyńców. Można jednak przypuszczać, że dokończono w ten sposób budowę programu liturgicznego poświęconego najważniejszym patronom Rzeczypospolitej i Krakowa. W r. 1715 św. Józef ogłoszony został szczególnym opiekunem miasta, a jego patronat bardzo sobie w Krakowie ceniono ${ }^{\mathrm{Il}}$.

W dniu 30 kwietnia 1753 r. biskup krakowski Andrzej Stanisław Kostka Załuski wyjeżdżając ze swego pałacu w Kielcach w Radomskie zwrócił się do krakowskiej kapituły katedralnej z prośbą o doglądanie przygotowań do uroczystości rocznicowych. Biskup prosił w nim: „Niechże wszystkie Venerabilis capituli kierują się conatus pro gloria Dei et Ecclesia Ejus, dlaczego następująca pięciusetletnią rocznicę kanonizacji S. Stanisława pamięci Waszych Miłości Panów insinuo..."12. Przejawem owych starań była operacja przeniesienia nagrobka króla Władysława Jagiełły do kaplicy Świętokrzyskiej. Tumba stojąca „a cornu Epistolae Sepulchri s. Stanislai” musiała przeszkadzać, dlatego zdecydowano się ją przenieść „propter commoditatem celebrantium et maius ornamentum Ecclesiae..." ${ }^{\prime 3}$. Nota o tym wydarzeniu zapisana została w Aktach Krakowskiej Kapituly Metropolitalnej pod datą 22 sierpnia, podobnie jak opis planowanych uroczystości. Decyzję o spisaniu ich przebiegu kapituła podjęła na swym posiedzeniu pro memoria futuris saeculis. Według tego tekstu, głównym elementem dekoracji okolicznościowych miała być „słusznej wielkości” struktura wzniesiona pośrodku nawy głównej, przed grobem świętego ${ }^{14}$. Pełniła ona funkcję tronu, na szczycie którego umieszczony miał być relikwiarz na głowę Stanisława roboty Marcina Marcińca. Strukturę zamierzano ozdobić herbami świętego i światłami, ponad nią zaś zawiesić baldachim ze skrzydłami rozchodzącymi się na boki. $Z$ dwóch stron relikwiarza ustawiono dwa orły, poniżej zaś kolejne dwa trzymające infułę i pastorał. W czterech narożach tak przygotowanego tronu stanąć miały cztery „,columnae" ozdobione światłami, po bokach ołtarza św. Stanisława zaś kolejne dwie ze światłami i malowanymi insygniami

${ }^{10}$ Lepiarczyk, Przybyszewski, dz. cyt., s. 27.

${ }^{11}$ B. J. W a n a t, Kult świętego Józefa Oblubieńca NMP u Karmelitów Bosych $w$ Krakowie, Kraków 1981, szczególnie s. 153-156.

${ }^{12}$ Fabrica Ecclesiae Cracoviensis..., no 214, s. 99.

${ }^{13}$ Fabrica Ecclesiae Cracoviensis..., no 215, s. 100. O przeniesieniu nagrobka ostatnio: $\mathrm{K}$. C h r u bas i k, Usytuowanie ptyty nagrobnej króla Wtadystawa Jagietły, „Biuletyn Historii Sztuki", LVII, 1-2, 1995, s. 133-136.

${ }^{14}$ Fabrica Ecclesiae Cracoviensis..., n. 216, s. 100-101. 
biskupimi. Na rozpoczęcie uroczystości krakowski ordynariusz miał wynieść ze skarbca relikwiarz i w towarzystwie prałatów, kanoników oraz chóru katedralnego złożyć go na tronie, później zaś pójść do ołtarza głównego, aby poprowadzić nieszpory. Nazajutrz odprawić miano mszę świąteczną czytaną a później uroczystą mszę śpiewaną o św. Stanisławie z Credo i Gloria. Przed rozpoczęciem nieszporów we wszystkich kościołach Krakowa miały bić dzwony a rozstawione armaty strzelać aż do zakończenia uroczystości. Po odśpiewaniu Te Deum biskup miał zdjął relikwiarz z podwyższenia i przy wtórze Gaude Mater Poloniae zanieść go $\mathrm{z}$ powrotem do skarbca. Przez cały ten czas wśród ludu rozprowadzać miano ksiażeczki z żywotem św. Stanisława po polsku i łacinie oraz okolicznościowe obrazki.

Opis zakończonych już uroczystości wprowadzony został pod dniem 10 września do Acta Officialia prowadzonych przez kanonika Mikołaja Lipskiego $^{15}$. Ma on charakter sumarycznej relacji spisanej ,ad perpetuam rei memoriam". Rocznicę celebrowano w dniu 8 września, w święto Narodzenia Matki Boskiej: „qua scilicet die octava septembris anno salutis humanae 1253 oraculo summi in terris pontificis Innocentii IV Regni nostri patronus et praesul urbis Cracoviae Stanislaus inter Sanctos martyres relatus fuit”. Dzień wcześniej w udekorowanym i dobrze oświetlonym wnętrzu katedry obchody rozpoczęto od uroczystych nieszporów. Po ich zakończeniu oddano salwy z 36 dział ustawionych w różnych częściach miasta leżących poza murami. Tuż po godzinie trzeciej po południu zaczął bić Zygmunt, a za nim wszystkie krakowskie dzwony. Podobnie stało się o godzinie siódmej wieczorem, a następnego dnia o godzinie siódmej rano i o szóstej po południu na zakończenie uroczystości. Główną mszę świąteczną celebrował gościnnie biskup inflancki Antoni Ostrowski, a ordynariusz krakowski czytał mszę przy grobie świętego. W czasie mszy głównej kazanie wygłosił profesor świętej teologii Antoni Krzanowski, kanonik kolegiaty św. Floriana ${ }^{16}$. Na zakończenie obchodów, w których uczestniczył cały krakowski kler oraz bractwa, odśpiewano Te Deum, a biskup udzielił zgromadzonym błogosławieństwa. Po nim uformowała się procesja, która przy wtórze antyfony Vir inclyte Stonislae wyruszyła od ołtarza głównego w stronę tronu w nawie głównej, gdzie od początku uroczystości spoczywała głowa świętego. Wraz z relikwią procesja przeszła obok grobu męczennika, a zakończyło ją odśpiewanie Gaude Mater Polonia. Po zakończeniu uroczystości w katedrze biskup przeszedł do kościola Franciszkanów, gdzie odczytano bullę beatyfikacyjną Józefa z Kupertynu i odśpiewano Te Deum, sławiąc Boga za ła-

\footnotetext{
${ }^{15}$ Fabrica Ecclesiae Cracoviensis..., n. 217, s. 101-102.

${ }^{16}$ Poproszony o to Józef Załuski, kanonik krakowski i referendarz królewski, nie mógl przybyć z powodu choroby.
} 
skę nowego błogosławionego. Po uroczystym błogosławieństwie biskup udał się na spoczynek do swojego pałacu. Pod jego nieobecność nieszpory u braci mniejszych odprawił kanonik i prekonizowany sufragan krakowski Franciszek Potkański. Uroczystości ku czci nowo beatyfikowanego trwały przez trzy dni, a uświetniło je bicie w dzwony, kanonady i pokazy ogni sztucznych.

Rozmach i bogata oprawa artystyczna opisanych uroczystości jubileuszowych wiązały się z pewnością ze świetną formacją intelektualną ówczesnego pasterza krakowskiego Kościoła - biskupa Andrzeja Stanisława Kostki Załuskiego ${ }^{17}$. Zatroszczył się on między innymi o jubileuszowe wydawnictwo: $Z e$ branie życia, cnót heroicznych S. Stanisława za staraniem An. St. Zatuskiego do druku podane 1753 Kraków, w druk. Biskup ${ }^{18}$. Możemy się domyślać, że to ten druk rozdawany był $\mathrm{w}$ czasie trwania katedralnych uroczystości. O próbie propagowania rocznicy poza granicami Rzeczypospolitej świadczy wydany w Rzymie staraniem Załuskiego żywot świętego Stanisława, będący skrótem z Jana Długosza. W jego ostatnim rozdziale znalazło się krótkie omówienie uroczystości rocznicowych ${ }^{19}$.

Uroczystości religijne i ich oprawa artystyczna nigdy nie cieszyły się szczególnym zainteresowaniem historyków sztuki w Polsce. Prace, które podejmują tę problematykę, dotyczą na ogół zagadnień ceremonialnych - pogrzebów, ślubów, koronacji królewskich, bądź też uroczystości świeckich ${ }^{20}$. Tematyka świąt religijnych podejmowana jest wyjątkowo rzadko. W przypadku Krakowa dysponujemy szczęśliwie pionierskim opracowaniem Michała Rożka, niemniej i w tej fundamentalnej monografii dostrzec można sporo luk, a ceremonie religijne zajmują najmniej miejsca ${ }^{21}$. Charakteru dekoracji okolicznościowych przygotowanych w r. 1753 nie da się niestety odtworzyć. Można na-

${ }^{17} \mathrm{Na}$ temat działalności fundacyjnej biskupa ostatnio: M. B a n a c k a, Fundacje sakralne biskupa Andrzeja Stanistawa Kostki Zatuskiego, [w:] Studia nad sztukq renesansu i baroku, t. 4, red. J. Lileyko, Lublin 2000, s. 217-252; Eadem, Biskup Andrzej Stanistaw Kostka Zatuski i jego inicjatywy artystyczne, Warszawa 2001. W pracach tych brak wzmianek na temat uroczystości krakowskich w r. 1753.

${ }^{18}$ E s t r e i c h e r, Bibliografia polska, t. 34, z. 1, Kraków 1951, s. 178-179; T. U l e w i c z, Sw. Stanistaw w kulturze dawnej Polski, ACr 11 (1979), s. 492.

${ }^{19}$ Compendio della vita, virtu e miracoli di s. Stanislao Vescovo di Cracovia e protomartire del Regno di Polonia In Roma MDCCLIII. Presso gli Eredi Barbiellini Mercanti di Libri, e stampori a Pasquino. Con Licenza de superiori (kolejne wydanie ukazało się w r. 1767 w drukarni Salomoni); por. K. E s t r e i c h e r, Bibliografia polska, t. 15, Kraków 1897, s. 243; U 1 e w i c z, dz. cyt., s. 492-493.

${ }^{20}$ Trzeba by w tym miejscu przywołać cały szereg świetnych prac historyków sztuki nowożytnej. Z braku miejsca odesłać się trzeba do bibliografii zebranej ostatnio w: S. Mossakowski, Uroczystości wawelskie w styczniu roku 1649 a projekty Giovanniego Battisty Gisleniego, „Studia Waweliana" IX/X (2000/2001), s. 41-83.

${ }^{21}$ M. R o ż e k, Uroczystości w barokowym Krakowie, Kraków 1976. 
tomiast zastanowić się jak wyglądała przygotowana na tę okoliczność architektura okazjonalna ${ }^{22}$. Interesujący zabytek późnobarokowej sztuki efemerycznej stanowiła opisana struktura - tron na relikwiarz św. Stanisława, określana w cytowanych źródłach jako „opus artificiosum” lub „feretrum”.

Poszukując genezy i odpowiedników dla tej ciekawej budowli trzeba rozpatrzyć kilka odmiennych w charakterze grup dzieł sztuki. Po pierwsze przeznaczenie tronu wiązało się ściśle $\mathrm{z}$ obyczajem uroczystego ukazywania, wystawiania, czy też prezentacji relikwii. „Ostensio reliquiarum" dokonywać się mogło $w$ różnych miejscach i na bardzo różne sposoby ${ }^{23}$. Jak powszechnie wiadomo, jedną $z$ istotnych funkcji pierwszych ołtarzy w kształcie szafy zaopatrzonej w skrzydła było przechowywanie i ukazywanie wiernym zgromadzonych wewnątrz relikwii ${ }^{24}$. Ojcowie soboru trydenckiego przykładali do spraw kultu relikwii duże znaczenie. Znalazło to pewien wyraz w postanowieniach soboru, który w swojej dwudziestej piątej sesji w dniach 3-4 grudnia 1563 r. wypowiedział się „O wzywaniu, czci, oraz relikwiach świętych i o świętych obrazach"25. Uwagi bardziej praktyczne znalazły się natomiast w Instructiones fabricae Karola Boromeusza, w rozdziale XVI zatytułowanym „De locis, vasis loculisque, quibus sacrae reliquiae reconduntur"26. Czytamy w nim między innymi, że reli-

${ }^{22}$ Pojęcia dekoracje okolicznościowe i architektura okazjonalna wprowadził J. A. C h r o ś c i c k i, Architektura okazjonalna XVI-XVIII wieku w Polsce. Próba charakterystyki [w:] Treści dziata sztuki. Materiaty Stowarzyszenia Historyków Sztuki, Gdańsk, grudzień 1966, Warszawa 1969, s. 215-234, szczególnie s. 215-216; Tenże, Pompa funebris. Z dziejów kultury staropolskiej, Warszawa 1974, s. 95-125.

${ }^{23} \mathrm{H}$. K ü h n e, Ostensio Reliquiarum. Untersuchungen über Entstehung, Ausbreitung und Funktion der Heiltumsweisungen im Romisch-Deutschen Regnum (Arbeiten zur Kirchengeschichte, New York 2000.

${ }^{24}$ J. B r a u n, Der Christliche Altar in seiner Geschichtlichen Entwicklung, Bd. 2, München 1924, s. 545-573; H. K e 11 e r, Die Flügelaltar als reliquienschrein, [w:] Studien zur Geschichte der europäischen Plastik. Festschrift für Theodor Müller, München, s. 125n.; A. L e g n e r, Reliquien in Kunst und Kultur zwischen Antike und Aufklärung, Darmstadt 1995, s. 173-198; K. S zcze pk ow sk a-N a liw a j e k, Gotyckie retabula relikwiarzowe - kilka spostrzeżen, [w:] Sztuka okoto 1400. Materiahy Sesji Stowarzyszenia Historyków Sztuki, Poznań, listopad 1995, Warszawa 1996, t. 2, s. 43-57. Szczegółowe opracowanie genezy i funkcji najstarszych ołtarzy skrzydłowych oraz przegląd wszystkich stanowisk w tej kwestii por. N. W o lf, Überlegungen zur Entstehung, Funktion und Verbreitung der deutschen Schnitzretabel des I4. Jahrhunderts, [w:] Figur und Raum. Mittelalterliche Holzbildwerke im historischen und kunstgeographischen Kontext, hrsg. von U. Albrecht, J. von Bonsdorff in zusammenarbeit mit A. Henning, Berlin 1994, s. 91-111; Tenże, Deutschen Schnitzretabel des 14. Jahrhunderts, Berlin 2002, szczeg. s. $356-361$.

${ }^{25}$ Postanowienia Soboru Trydenckiego. Dwudziesta piqta Sesja Soboru Trydenckiego, a dziewiqta i ostatnia za pontyfikatu Piusa IV rozpoczęta 3, a zakończona 4 dnia grudnia 1563 , [w:] Teoretycy, pisarze i artyści o sztuce 1500-1600, wybrał i opracowal J. Białostocki (Historia doktryn artystycznych, wybór tekstów, t. II), Warszawa 1985, s. 390-393.

${ }_{26}$ Trattati d'arte del Cinquecento fra Manierismo e Controriforma, a cura di P. Barocchi, vol. III, Bari 1962, s. 36-42; Carlo Borromeo Arte Sacra (De fabrica Ecclesaie), versione e note 
kwie, które znajdują się w kościołach posiadających podziemną część zwaną confesio, a w języku potocznym scurolum, powinny być przechowywane właśnie tam, wewnątrz kamiennego ołtarza lub pod nim. Autor podkreśla antyczne źródła tego zwyczaju (,ut antiqui instituti est”), przejawiając tym samym typowy dla swego czasu szacunek dla wzorów wczesnochrześcijańskich ${ }^{27}$. Dalej podnosi on znaczenie oddzielnego przechowywania odseparowanych od ciał głów świętych, które dzięki temu mogą być ukazywane wiernym w dni świąteczne. Relikwiarze przeznaczone do tego celu powinny być wykonane ze złota, srebra lub brązu i naśladować kształt głowy razem z szyją i częścią tułowia. Jeśli ciało jest nie podzielone, może być przechowywane w ołtarzu albo w specjalnym relikwiarzu. Ołtarz ten lub relikwiarz powinny być skonstruowane w taki sposób, aby z przodu znajdował się niewielki otwór zaopatrzony w kratę z brązu, zamykany za pomoca solidnych drzwi, żeby w święta można było oglądać znajdujące się wewnątrz szczątki. Tekst zawiera opis trzech sposobów przechowywania relikwii dopuszczonych w kościołach na wzór bazylik Rzymu. W nawach dużych kościołów po stronie Ewangelii można zbudować podest wsparty na kamiennych kolumnach. Na nim może być ustawione kamienne, bogato dekorowane tabernakulum służące do przechowywania szczątków świętych. Musi być ono zamykane solidnymi drzwiami, nie może natomiast mieć stałych schodów; wolno używać tylko przenośnych schodków i to w dni świateczne, gdy relikwie trzeba pokazywać zgromadzonym wiernym. W mniejszych świątyniach trzeba budować podobne tabernakula, ale usytuowane bliżej ołtarza głównego, przy ścianie. Tu można budować stałe schody, byle tylko nie zajmowały one miejsca w nawie. W trzecim przypadku można zastosować niszę wykutą w ścianie. Relikwiarze przechowywane wewnątrz tak przygotowanych schowków mają być ze złota, srebra, kryształu lub innego rodzaju metalu. Mają być udekorowane stosownie do rangi relikwii, które mieszczą. Nie wolno mieszać $w$ ich wnętrzach rodzajów relikwii, wszystkie one natomiast muszą być posegregowane i przechowywane oddzielnie. Tkaniny używane wewnattrz relikwiarzy mają mieć kolor odpowiedni do rodzaju relikwii. Każda relikwia ma być opisana z pomocą przyczepionej do niej pergaminowej kartki. Również na

a cura di C. Castiglioni, C. Marcora, Milano 1952, s. 50-54; E. C. V o e $1 \mathrm{ke} \mathrm{er,} \mathrm{Charles} \mathrm{Borro-}$ meo's Instructiones fabricae et supellectilis ecclesiasticae, 1577. A Translation with Commentary and Analysis, Ann Arbor Univeristy Microfilms 1977, s. 207-218.

${ }^{27}$ O popularności konfesji na szerokim tle odrodzenia sztuki wczesnochrześcijańskiej w. czasach potrydenckich pisza m.in. A. Her z, Cardinal G. Baronio's Restauration of SS. Nereo $e$ Achilleo and S. Cesareo de 'Appia, „The Art Bulletin”, LXX, 4, 1988, s. 590-620, szczególnie s. 600-601; M. G. Turco, Il Titulus dei santi Nereo e Achilleo emblema della riforma cattolica, Roma 1997. Szeroko na temat zainteresowań historią i ich odbicia w sztuce w. XVII: G. Bickendorf, Die Historisierung der Italienischen Kunstbetrachtung im 17, und 18. Jahrhundert (Berliner Schriften zur Kunst, Bd. XI), Berlin 1998. 
relikwiarzu powinna znajdować się informacja jakiego rodzaju szczątki kryje. W pobliżu miejsca przechowywania relikwii powinny być umieszczone wizerunki świętych, których szczątki znajdują się w kościele, ze szczególnym uwzględnieniem postaci najznaczniejszych. Na koniec wreszcie, $w$ kościele powinna znajdować się brązowa lub kamienna tablica ze spisem relikwii przechowywanych wewnątrz wmurowana w widocznym miejscu.

Autor wspomnianych zaleceń, Karol Boromeusz, rozpoczął intensywne działania zmierzające do reformy kultu relikwii w swej własnej diecezji. Świadczą o tym m.in. akta synodu diecezjalnego z r. 1565 zachęcające, aby święte szczątki: „cum populo pietatis causa ostenduntur, lumina accendantur” ${ }^{28}$. Wielki ojciec soboru trydenckiego był też wielkim propagatorem translacji relikwii. Uroczystości i dekoracje, które im towarzyszyły, były, obok propagowania kultu lokalnych świętych i ożywiania miejscowych tradycji Kościoła średniowiecznego, jednym ze środków budowania wizerunku Mediolanu jako drugiego Rzymu ${ }^{29}$.

Jakob Müller w wydanym w Monachium w r. 1591 dziele Ornatus ecclesiasticus (niem. Kirchen Geschmuck) na s. 113 zamieścił rycinę, która stanowić miała wzór świątecznej aranżacji ołtarza (il. 1) ${ }^{30}$. Ów ,der festlich bereitete Altar" ma formę mensy wyniesionej na kilku stopniach z nastawą w formie tryptyku z ruchomymi skrzydłami. Pośrodku znajduje się tabernakulum w kształcie tempietta otoczone świecznikami. Pomiędzy nim a dolną krawędzią nastawy umieszczone są dwa stopnie nakryte obrusami, na których ustawione zostały relikwiarze o różnych ksztaltach. W okresie kontrreformacji to właśnie ołtarz główny kościoła stał się najważniejszym miejscem wystawiania relikwii. Świadczą o tym między innymi statuty synodalne poszczególnych diecezji, układane w myśl zasad Tridentinum ${ }^{31}$. W Kolonii (która w badaniach nad kultem relikwii zajmuje miejsce szczególne) arcybiskup Ferdynand z Bawarii zasiadający na swej stolicy od r. 1612, przybrawszy sobie dewizę „Avita fide”, poświęcił się

${ }^{28} \mathrm{~V}$ o e $1 \mathrm{k}$ e r, dz. cyt., s. 219-220.

${ }^{29}$ S. M a y e r-H i m m e l h e b e r, Bischöfliche Kunstpolitik nach dem Tridentinum. Der Secunda-Roma-Anspruch Carlo Borromeos und die mailändischen Verordnungen zu Bau und Austattung von Kirchen, München 1984, szczególnie s. 18-21.

${ }^{30}$ Jakob Müller, wykształcony wszechstronnie w Rzymie, gdzie przebywał w Collegium Germanicum, pisał swe dzieło jako administrator diecezji ratyzbońskiej. Stanowi ono bardzo ważny przyklad realizacji wytycznych zawartych w Instructiones fabricae Karola Boromeusza. Ukazały się równocześnie wersje lacińska i niemiecka, z których tylko niemiecka była ilustrowana. Zagadnienie to omówiła szczególowo F. S tre cke r, Augsburger Altäre zwischen Reformation (1537) und 1635. Bildkritik, Repräsentation und Konfesionalisierung, Münster 1997, s. 80-87.

${ }^{31}$ A. S chom mers, Rheinische Reliquiare. Goldschmiedearbeiten und Reliquieninzenierungen des 17. Und 18. Jahrhunderts, Rheinbach-Merzbach 1993, s. 192-200. 
wcielaniu w życie ustaw soboru ${ }^{32}$. Zwołany przez niego w r. 1627 synod ostatni punkt statutów zatytułował De veneratione Sanctorum, Reliquiis et earum catalogo conficiendo ${ }^{33}$. Zgodnie $\mathrm{z}$ duchem ustaw soborowych statut ten nakazywał, aby we wszystkich kościołach, kaplicach i oratoriach przechowywane tam relikwie zostały zgromadzone w jednym miejscu i zabezpieczone. Nie wolno było wywozić ich poza granice diecezji bez zgody biskupa. Napisy na relikwiarzach powinny zostać odnowione, jeśli istnieje taka potrzeba. Każdy kościół w ciągu dwóch miesięcy od ogłoszenia statutów powinien był przygotować dokładny spis relikwii zawierający informacje na temat ich pochodzenia i autentyczności. Zabezpieczone w ten sposób szczątki miały być udostępniane wiernym, w sposób szczególny w dni świąteczne. Wówczas relikwie świętego, którego święto właśnie obchodzono, powinny być podane wiernym do uczczenia poprzez wystawienie na ołtarzu, lub $\mathrm{w}$ innym stosownym miejscu ${ }^{34}$. W taki najczęściej sposób oddawano cześć relikwiom nowych świętych lub błogosławionych w czasie uroczystości obchodzonych w różnych kościołach Rzymu. W czasie uroczystego triduum po beatyfikacji Andrzeja Contiego w r. 1724 jego relikwie wystawiono na ołtarzu głównym w kościele S. Maria in Aracoeli ${ }^{35}$. W czasie oktawy kanonizacji św. Franciszka de Regis w r. 1737 jego relikwiarz wystawiono pośrodku ołtarza głównego w kościele del Gesư ${ }^{36}$. Szczątki Wincentego à Paulo uczczono po jego kanonizacji w r. 1738 w czasie oktawy w kościele SS. Trinità a Montecitorio ${ }^{37}$. Taki sposób prezentacji relikwii ukazują też oficjalne druki poświęcane świętym patronom. Przykładowo tytułowa rycina Żywota św. Simpertusa wydanego w Augsburgu w r. 1792 ukazuje rokokowy ołtarz, na którym wystawione zostały różne relikwie, pośrodku zaś ponad tabernakulum i pod rozbudowanym baldachimem spoczywa głowa świętego nakryta mitrą biskupia [il. 2] $]^{38}$.

\footnotetext{
${ }^{32} \mathrm{Na}$ temat znaczenia Kolonii jako wielkiego ośrodka kultu relikwii ostatnio: A. L e g n e r, Kölner Heilige und Heiligtümer. Ein Jahrtausend europäischer Reliquienkultur, Köln 2003.

${ }^{33}$ Statuty zostały wydrukowane w drukarni Piotra Cholinusa w tym samym roku; Synodus dioecesana Coloniensis habita anno millesimo sexcentesimo vigesimo septimo, decimo nono Aprilis. Sub reverendissimo et serenissimo principe ac domino, domino Ferdinando archiepiscopo et principe electore Coloniensi, Coloniae Agrippinae apud Petrum Cholinum Anno 1627; por. J. F. S c h a n n at, P. J. H a r tz h e i m, Concilia Germaniae, Bd. 9, Köln 1771, s. 406-412.

${ }^{34}$ Statuty te omówiła szczegółowo Schommers, dz. cyt., s. $46 \mathrm{n}$.

${ }^{35}$ Corpus delle feste a Roma, vol. 2: Il Settecento e l'Ottocento, a cura di M. Fagiolo, Roma 1997, s. 46-47.

${ }^{36}$ Tamże, s. $100-101$.

${ }^{37}$ Tamże, s. 102.

${ }^{38}$ Geschichte von dem Leben (...) Bischofs Simpert, Augsburg 1792; por. Sankt Simpert, Bischof von Augsburg 778-807. Ein hochverehrter Heiliger und Nothelfer in Stadt ud Bistum Augsburg, Augsburg 1978, il. 42.
} 
W czasach nowożytnych szczególnym przejawem kultu relikwii świętych stał się zwyczaj translacji ciał odnajdywanych w katakumbach na terenie Rzymu. Od końca w. XVI w katolickich krajach Europy ilość translationes zaczęła gwałtownie wzrastać, a formy okazywania czci nowym męczennikom stawały się coraz bardziej wyszukane ${ }^{39}$. Charakterystycznym rysem tej potrydenckiej pobożności, szczególnie w krajach habsburskich, było eksponowanie w ołtarzach całych ciał, bądź też ich części odzianych w prawdziwe stroje i przystrojonych $\mathrm{w}$ dekoracje $\mathrm{z}$ kamieni lub cekinów ${ }^{40}$. Stroje te miały często charakter antykizujący i określały stan lub profesję męczennika. W celu zwiększenia realizmu ciała eksponowano najczęściej w pozycji stojącej bądź półleżącej; niekiedy też ubierano je w woskowe maski, nadając tym samym charakter swoistych rzeźb. Przywożone z Rzymu kości traciły w ten sposób anonimowość i zyskiwały nowe „życie”. Kościół stawał się dworską aulą audiencjonalną, salą tronową, w której tronujący na ołtarzach święci przyjmowali wizyty wznoszących modły interesantów ${ }^{41}$. Dobrym przykładem takiego sposobu ekspozycji relikwii jest ołtarz św. Notburgi w tyrolskim Eben [il. 3 $]^{42}$. W rokokowej strukturze wzniesionej około połowy w. XVIII pole środkowe, rezerwowane najczęściej dla wizerunku świętego, wypełnione zostało przez szczątki sprowa-

${ }^{39}$ Zagadnienia te omówił najpełniej H. A c h e r m a n n, Die Katakombenheiligen und ihre Translationen in der Schweizerischen Quart des Bistums Konstanz (Beiträge zur Geschichte Nidwaldens, Heft 38), Stans 1979, szczeg. s. 7-23; Idem, Translationen heiliger Leiber als barockes Phänomen, „Jahrbuch für Volkskunde”, Neue Folge, 4, 1981, s. 101-111; por. też A. S c h o m m e r s, dz. cyt., s. 70-82; A. A n g e n en d t, Heilige und Reliquien. Die Geschichte ihres Kultes vom frühen Christentums bis zur Gegenwart, München 1994, s. 250-251; A. P o 1 o n y i, Reliquien aus den römischen Katakomben, [w:] Gold, Perlen und Edel-Gestein. Reliquienkult und Klosterarbeiten im deutschen Südwesten, Austellung Augustiner Museum Freising, München 1995, s. $9-19$.

${ }^{40} \mathrm{~B}$ r a u n, dz. cyt., s. 572-573; U. B r o s e t t e, Die Inszienierung des Sakralen. Das theatralische Raum- und Austattungsprogramm süddeutscher Barockkirchen in seinem liturgischen und zeremoniellen Kontext, Bd. 1-2 (Marburger Studien zur Kunst - und Kulturgeschichte, Hg. I. Herklotz, K. Niehr, U. Schütte, Bd. 4), Weimar 2002, s. 328, 333, 339, 343, 344-345, il. 206-212; L e gne r, Reliquien..., s. 289-315. O sposobach dekorowania takich relikwii por. A c h e rm a n n, dz. cyt., s. 79-87; A. L e g n e r, Vom Glanz und von der Präsenz des Heiltums Bilder und Texte [w:] Reliquien. Verehrung und Verklärung. Skizeen und Noten zur Thematik und Katalog zur Austellung der Kölner Sammlung Louis Peters im Schnütgen-Museums, hrsg. von A. Legner, Köln 1989, s. 128-139; S. B o c k, Freiburger Klosterfrauenarbeiten des 17. Und 18. Jahrhunderts [w:] Gold, Perlen und Edel-Gestein..., s. 30-40; M. S c h ü 11 y, Klosterarbeiten im Augustinermuseum und in der Sammlung der Erzdiözese Freiburg [w:] tamże, s. 41-57.

${ }^{41}$ B r o s e t t e, dz. cyt., Bd. 1, s. 330-332.

${ }^{42}$ Ołtarz św. Notburgi ukazuje sztych F. X. Jungwirtha wydany w: J. Periero, Acta Sanctae Notburgae, Antwerpia 1753; por. F. Car a me lle, W. In g e h h eff, P. O r lik, L. Penz, Sankt Notburga. Die Volksheilige aus Tirol in Geschichte, Kult und Kunst, Hall in Tirol 1996, s. 48 , il. 45 . 
dzone z Rzymu i wyeksponowane w pozycji stojącej w wymyślnym stroju pokrytym bogatą dekoracja.

Zagadnienie przyjmowania w Rzeczpospolitej potrydenckich praktyk w zakresie sztuk plastycznych nie było jak dotąd przedmiotem szerszych badañ ${ }^{43}$. To samo dotyczy przemian w zakresie kultu relikwii ${ }^{44}$. Z pewnością jednak i tutaj ogromną rolę odgrywała tradycja lokalna. O ile na Mazowszu próbowano przeszczepić obcą w Polsce formę konfesji, o tyle w Małopolsce nieprześcignionym wzorem był grób w formie skrzyni ustawionej na ołtarzu ${ }^{45}$. Punktem odniesienia był oczywiście „Ołtarz Ojczyzny” stojący na skrzyżowaniu naw krakowskiej katedry. W wyniesionych trumnach ze srebrnej blachy fundowanych kolejno przez Elżbietę Lokietkównę, Zygmunta III Wazę i biskupa Piotra Gembickiego spoczywały tu szczątki najważniejszych patronów Krakowa św. św. Stanisława i Floriana ${ }^{46}$. Można przypuszczać, że istniała jeszcze jedna, najstarsza trumna

${ }^{43}$ Pośród niewielu prac dotyczących tego zagadnienia warto wymienić niepublikowaną wciąz pracę: $\mathrm{O}$. M i k o l aj s k i, Recepcja trydenckiego dekretu o obrazach w polskim ustawodowstwie synodalnym, praca magisterska napisana w r. 1988 w Instytucic Historii Sztuki Uf w Krakowie pod kierunkiem dr. hab. A. Małkiewicza.

${ }^{44}$ Problematyka polskich, a w wẹższym zakresie krakowskich zbiorów relikwii nigdy nie była przedmiotem osobnych studiów; por. uwagi i postulaty badawcze w: M. S ta rn a w ska, Rozmieszczenie i struktura zbiorów relikwii w polskich miastach średniowiecznych [w:] Ecclesia et civitas. Kościót $i$ życie religijne $w$ mieście średniowiecznym, red. H. Manikowska, H. Zaremska, Warszawa 2002, s. 453-462. Zagadnienie to wymaga odrębnej kwerendy źródłowej, która trudno było podjąć przy okazji niniejszego artykułu. Stąd przypadkowość zawartych poniżej spostrzeżeń, $z$ której autor zdaje sobie sprawę w całej pełni.

${ }^{45} \mathrm{R}$. Mą czy ńs ki, Warszawska konfesja rzymskich męczenników, „Biuletyn Historii Sztuki" XLVII, 1-2, 1985, s. 45-72; Idem, Warszawa XVII $i$ XVIII wieku jako centrum kultu relikwii swiętych [w:] Historyczne centrum Warszawy. Urbanistyka, architektura, problemy konserwatorskie. Materiaty sesji naukowej, Warszawa 23-24 maja 1996, red. B. Wierzbicka, Warszawa 1998 , s. 80-99.

${ }^{46}$ Poważne problemy badacze stwarza pierwsza znana ze źródeł pisanych trumna. Badacze łączyli jej powstanie z księżną krakowską Kingą Władysławem Łokietkiem, Elżbietą Lokietkówna królową Jadwiga a nawet z Władysławem Jagiełłą i kardynałem Zbigniewem Oleśnickim; por. przegląd stanowisk w: M. K o c h a n o w s k a - R e i c h e, Najstarsze cykle narracyjne $z$ legendq św. Stanistawa biskupa, „Ikonotheka. Prace Instytutu Historii Sztuki Uniwersytetu Warszawskiego", 3, 1991, s. 36. Słuszna okazała się opinia wyrażona już w w. XIX przez ks. I g n a c e go Polkowski ego, Grób i trumna św. Stanistawa Biskupa i Męczennika na Wawelu, „Sprawozdania Komisyi do Badania Historyi Sztuki w Polsce", 3, 1884, s. 32. Fundację Elżbiety Lokietkówny potwierdzała inskrypcja wzmiankowana w ogłoszonych drukiem zapiskach księdza Jana Wielewickiego; J. Wi i le w i ck i, Dziennik spraw domu zakonnego oo. Jezuitów u św. Barbary w Krakowie, t. 5: 1630-1639, Kraków 1999, s. 97-98: „... cista (...) a regina Poloniae, matre Ludovici regis, fuisse comparatum plusquam a ducentis annis...”; Ibidem, s. 104: „Porro cistam hanc maiorem, ut ex eius inscriptione manifestum est, Elisabeth Hungariae et Poloniae regina, regis Ludovici Hungari mater, ante annos plusquam 200 S. Stanislao Cracoviensi episcopo miserat". W świetle tego źródła zrozumiały staje się zapis w Acta Actorum katedry krakowskiej 
ufundowana z okazji kanonizacji św. Stanisława w r. 1254. To ona zapewne stanowiła ogniwo łączące kolejne krakowskie dzieła $\mathrm{z}$ ich bezpośrednimi wzorami, jakimi są wielkie romańskie skrzynie relikwiarzowe $\mathrm{z}$ terenów położonych pomiędzy Renem i Mozą ${ }^{47}$. Za wzór w nowożytnym Krakowie mogły też służyć niektóre gotyckie ołtarze skrzydłowe, takie jak poliptyk św. Jana Jałmużnika ustawiony w krużgankach klasztoru augustianów na Kazimierzu $\mathrm{z}$ fundacji Mikołaja $\mathrm{z}$ Brzezia Lanckorońskiego ${ }^{48}$. W jego predelli znajdowały się relikwie świętych umieszczone w hermach. Część z nich, w tym partykuły św. św. Andrzeja, Hilariona, Pantaleona, Krzysztofa, Menasa, Szczepana, Magdaleny, Łucji, Dziesięciu tysięcy męczenników oraz Jedenastu tysięcy dziewic, została przywieziona przez Lanckorońskiego z Konstantynopola ${ }^{49}$. Znajdowała się tam także cząstka dalmatyki, w której złożono do grobu ciało św. Wojciecha. Relikwia ta przywieziona przez Lanckorońskiego z klasztoru w Trzemesznie upamiętniona została specjalną tablicą umieszczoną w pobliżu ołtarza ${ }^{50}$.

Kardynał Jerzy Radziwiłł w sposób szczególnie aktywny zajmował się wprowadzaniem w życie ustaleń Tridentinum ${ }^{51}$. Wiadomo, że miał on zwyczaj

(t. 13, k. 163v.) z r. 1633 o: ,veterem tumbam cineribus sancti Stanislai ab Helizabeth regina constructam, qua in sacrsitia est reposita". Dotychczas uważano, że wzmianka ta wzięła się z mylnej identyfikacji relikwiarza na głowę św. Stanisława fundowanego przez Elżbietę Rakuszankę ze srebrną trumna; J. P i e tru siński, Jak wyglqdat wizerunek kanonizacyjny św. Stanistawa, „Rocznik Historii Sztuki”, 17, 1988, s. 37, przyp. 10. Por. też kategoryczne sformułowanie M. Ro ż k a, Ara Patriae. Dzieje grobu św. Stanisława w katedrze na Wawelu, ACr 11 (1979), s. 441, że: „nie ma (...) danych, by sądzić, że Jadwiga sprawiła nową trumnę, a już w żadnym wypadku królowa Elżbieta Łokietkówna". W świetle zapisów Wielewickiego trzeba przyjąć, że notka w Acta Actorum oparta była po prostu na autopsji inskrypcji zachowanej na trumnie.

${ }^{47} \mathrm{Na}$ ten temat ostatnio: P. K r a s n y, Relikwiarz św. Jozafata Kuncewicza w katedrze polockiej. Przyczynek do badań nad srebrnymi trumnami relikwiarzowymi w Rzeczypospolitej w XVII wieku, [w:] Studia nad sztukg renesansu i baroku, t. IV, red. J. Lileyko, Lublin 2000, s. $121-140$.

${ }^{48}$ W. K o la k, Klasztor Augustianów przy kościele św. Katarzyny w Krakowie do polowy XVI w., Krak6w 1982, s. 84-85; J. G a d o m ski, Gotyckie malarstwo tablicowe Matopolski 1500-1540, Warszawa-Kraków 1995, s. 52-53; U. B o rk ow s k a, Królewskie modlitewniki. Studium z kultury religijnej epoki Jagiellonỏw (XV i poczqtek XVI wieku), Lublin 1999, s. 220-221.

${ }^{49} \mathrm{O}$ działalności dyplomatycznej Mikołaja $\mathrm{z}$ Brzezia i jej związkach $\mathrm{z}$ fundacjami artystycznymi por. G a d o m s k i, dz. cyt., s. 31-32; S. C y n a r s ki, Dzieje rodu Lanckorońskich $z$ Brzezia od XIV do XVIII wieku. Sprawa kariery urzędniczej $i$ awansu majatkowego, Warszawa, Kraków 1996, s. 116; A. R ó ż y c k a - B r y z e k, Mikołaja Lanckorońskiego pobyt w Konstantynopolu w roku 1501 - nie tylko postowanie, „Folia Historiae Artium”, Seria Nowa 5/6, 2001, s. 79-92.

${ }^{50}$ Przewodnik abo kościotów krakowskich krótkie opisanie wydany w r. 1603 z widokami Krakowa, którego już nie ma, wyd. J. Kiliańczyk-Zięba, Kraków 2002, s. 102.

${ }^{51}$ Do đziś niezastapiona pozostaje praca: F. M a c h a y, Dziatalność duszpasterska kardynata Radziwitla, biskupa krakowskiego (1591-1600), Kraków 1936, s. 76-78 (gdzie krótki passus na temat troski o wyposażenie kościołów). 
częstego odprawiania mszy świętych przy grobie siostry Kingi w opactwie klarysek w Starym Sączu. Za każdym razem kazał umieszczać na ołtarzu srebrny relikwiarz z jej czaszka, a po skończonym nabożeństwie podawano go wiernym do ucałowania ${ }^{52}$. Działania takie stanowią przykład realizowania wytycznych soboru, z drugiej jednak strony nawiązywały one zapewne do tradycji lokalnych. W krakowskim kościele św. Floriana od późnego średniowiecza w każdy poniedziałek ręka świętego patrona wystawiana była na ołtarzu głównym ${ }^{53}$. Już w czasach nowożytnych w kościele św. Barbary na ołtarzu Stanisława Kostki wystawiano relikwie tego świętego oraz chustkę, którą ocierano pot $\mathrm{z}$ cudownego obrazu, niegdyś przywiezionego do Krakowa z Rzymu. Z kolei w kościele dominikanów obok zakrystii znajdował się ołtarz: „na którym stawiaią Relikwiarz wielki pełen Relikvij SS. Bożych" "54.

W tej samej świątyni braci kaznodziejów w kaplicy Różańcowej znajdował się ołtarz, w którego kolumnach eksponowane były relikwie oraz oddzielny altare reliqiarum, sprawiony ,za staraniem X. Franciszka Bystrzyckiego na ten czas Promotora Rożańca S.". Ołtarz relikwiarzowy znajdował się także w kościele św. św. Piotra i Pawła, w kaplicy przy prawym ramieniu transeptu. Relikwie zostały przeniesione $\mathrm{z}$ pompa $\mathrm{z}$ katedry $\mathrm{w}$ czasie uroczystości wielkiego jubileuszu w dniu 10 października 1626 r. a kilka lat później, 22 maja 1639 r. wraz $\mathrm{z}$ innymi umieszczone $\mathrm{w}$ specjalnym ołtarzu o dwunastu kolumnach z przeszklonymi loculi $i^{55}$. O rozmiarach i bogactwie tej kolekcji świadczą dane liczbowe. W ołtarzu umieszczono 14 ciał rzymskich męczenników, 13 głów (w tym głowę Stanisława Kostki), 12 ramion i 13 nóg różnych świętych. Pośród wielkiej ilości drobnych relikwii znalazły się 3 związane z Męką Pańską 16 partykuł apostołów i ojców Kościoła, 86 części ciał męczenników, 25 wyznawców oraz 31 świętych dziewic i matron. Ze względu na ilość translokowanych

${ }^{52}$ L. Kow als ki, S. F is ch e r, Żywot błogosławionej Kingi $i$ dzieje jej kultu, Tarnów 1992, s. 119; o zwyczaju wystawiania relikwii Kingi na ołtarzach Ibidem, s. 152.

${ }^{53}$ Tradycja ta siegala zapewne późnego średniowiecza i związana była ze staraniami biskupa Oleśnickiego o rozbudzenie kultu szczególnego patrona Kleparza; Kleynoty Stotecznego Miasta Krakowa..., dz. cyt., s. 158; K. D o b row o I s k i, Dzieje kultu św. Floriana w Polsce do polowy XVI w., Lwów, Warszawa 1923 (Rozprawy Historyczne Towarzystwa Naukowego Warszawskiego, 2/2), s. 70, 92, 116; A. W i t k o w s k a, Kulty pątnicze piętnastowiecznego Krakowa. $Z$ badań nad miejskq kulturq religijna, Lublin 1984, s. 87-88; M. W a l c z a k, Działalność fundacyjna biskupa krakowskiego kardynała Zbigniewa Oleśnickiego, cz. II, „Folia Historiae Artium" XXX, 1994, s. 78.

${ }^{54}$ Kleynoty Stotecznego Miasta Krakowa albo Koscioły, y co w nich iest widzenia godnego y znacznego przez Piotra Hiacyntha Pruszcza, krotko opisane, powtornie zaś z pilnośćia przeyźrzane, y do druku z additamentem nowych Kośćiotow y Relikwii S. Podane z pozwoleniem Zwierzchnośći Duchowney Roku Pańskiego 1745, s. 59, 82, 158.

${ }^{55}$ Tamze, s., 83, 115 . 
relikwii (i w zgodzie z zaleceniami Karola Boromeusza) ich spis umieszczony został przy wejściu do kaplicy i wydany drukiem staraniem archidiakona krakowskiego, wikariusza generalnego ks. Erazma Kretkowskiego ${ }^{56}$. Szczególna wersją ołtarza relikwiarzowego musiała być nastawa ustawiona pośrodku skarbca katedry. Była to podzielona kolumnami szafa zaopatrzona w drzwi rozsuwane za pomocą kołowrotów $\mathrm{z}$ korbami. Za zasuwami znajdowały się półki na relikwie $^{57}$.

Znacznie rzadziej relikwie wystawiane były na specjalnych galeriach bądź balkonach. Konstrukcje takie - najczęściej o średniowiecznej jeszcze metryce znajdowały sie w miejscach, gdzie kolekcje relikwii były wyjątkowo bogate i powszechnie nawiedzane. Wystarczy tu wymienić najsławniejsze, znajdujące się w paryskiej Sainte-Chapelle, przy katedrach w Akwizgranie, Wiedniu i Pradze, przy kościele Mariackim w Norymberdze czy na rynku Nowego Miasta w Pradze ${ }^{58}$. W Krakowie galeria służąca do wystawiania relikwiarza głowy św. Stanisława znajdowała się $\mathrm{w}$ nawie północnej katedry ${ }^{59}$. W nawie południowej w arkadzie prowadzącej do kaplicy Św. Piotra wystawiano relikwiarz ręki świętego, ustawiony na tle specjalnej srebrnej tablicy. Inwentarz katedry z r. 1563 podaje, że „relikwiarz ten, ozdabiany jedwabnymi tkaninami, umieszczany jest wedle zwyczaju na tablicy obitej srebrnymi blachami, na której jest trzynaście wielkich kamieni i osiem mniejszych, przy czym kolejnych ośmiu brakuje" [tłum. autor $]^{60}$. Niestety, nie możemy powiedzieć nic więcej na temat tych intrygujących zwyczajów. Ich znaczenie dostrzegał już autor najstarszego przewodnika po Krakowie, wydanego z okazji wielkiego jubileuszu chrześcijaństwa w r. 1603. Pisał on o kaplicy, „do której po wschodach chodzić, gdzie

${ }^{56}$ S. Z ał ę ski, OO. Jezuici przy kościele św. Piotra i Pawła w Krakowie. Szkic historyczny, Nowy Sącz 1896, s. 74-84; W i e 1 e w i c k i, op. cit., s. 555-556. Tablica ze spisem relikwii zachowała się do naszych czasów: Katalog zabytków sztuki w Polsce, t. IV: Miasto Kraków, cz. III: Kościoły i klasztory Śródmieścia, 2, red. A. Bochnak, J. Samek, Warszawa 1978, s. 70. Niestety znaczna część wyposażenia, w tym malowidła ścienne ukazujące sceny z życia św. Stanisława Kostki i procesję z okazji przekazania głowy Świętego jezuitom została zniszczona w czasie odnawiania kaplicy z inicjatywy Bractwa Trójcy Świętej w r. 1895; Tamże, s. 78.

${ }^{57} \mathrm{U}$ r b a n, dz. cyt., s. 25.

${ }^{58} \mathrm{O}$ zagadnieniu tym pisałem szeroko w: M. W a $1 \mathrm{c} \mathrm{z}$ a k, Przemiany architektoniczne katedry krakowskiej $w$ pierwszej potowie $X V w$. i ich zwiqzek $z$ działalnościa fundacyjna kardynata Zbigniewa Oleśnickiego, „Studia Waweliana”, I, 1992, s. 21-25; Idem, Działalność fundacyjna..., s. 77-78, gdzie zebrana najważniejsza literatura; z nowszych pozycji por. L e g ner, dz. cyt., s. 89-118, przede wszystkim zaś $\mathrm{K}$ ü h n e, dz. cỵt.

${ }^{59} \mathrm{~W}$ a $1 \mathrm{c} \mathrm{z}$ a k, Przemiany architektoniczne..., s. 7-28, szczególnie s. 19, 25.

${ }^{60}$ Inwentarz katedry wawelskiej z roku 1563, opracował A. Bochnak, Kraków 1979 (Źródta do dziejów Wawelu, t. X), Kraków 1979, s. 149-150; M. W a 1 c z a k, Pierścień zwany św. Stanistawa, [w:] Wawel 1000-2000. Wystawa jubileuszowa. Kultura artystyczna dworu królewskiego i katedry, t. I, Kraków 2000, kat. I/183, s. 208-209. 
głowa świętego Stanisława na święta jego wystawiana bywa" oraz o innej, „w stronę drzwi południowych, gdzie pierwszy grób świętego Stanisława był i do tego czasu jest tam ręka i pierścień, która w stacyje wystawiana bywa"61.

Szczególny sposób stałego eksponowania relikwii zapewniało ich wkomponowanie w mury budowli (na przykład w chórze katedry w Magdeburgu) i przegrody relikwiarzowe (niem. Reliquienschranke) charakterystyczne głównie dla Kolonii nad Renem. Ściany z przegrodami na relikwie znajdowały się tutaj między innymi w pomieszczeniu pod wieżą południową katedry i w kościołach św. św. Gereona, Kuniberta, Urszuli oraz w jezuickiej świątyni Wniebowzięcia Najświętszej Marii Panny ${ }^{62}$. Różnorodne formy prezentacji spotkać można w specjalnych kaplicach relikwiarzowych (niem. Heiltumskammern). Do najlepszych przykładów z doby nowożytnej należą tu „Reiche Kapelle” przy rezydencji w Monachium czy kaplica relikwii przy Monasterío de las Descalzas Reales w Madrycie ${ }^{63}$. Miejscem szczególnym jest też sławna Goldene Kammer przy kościele św. Urszuli w Kolonii. Ta średniowieczna kaplica, zaaranżowana na nowo w latach 1643-1644, jest przykładem barokowego Gesamtkunstwerku, gdzie rolę tradycyjnych materiałów używanych przez artystów przejęły relikwie. Jej ściany pokrywają niezwykłe ornamenta ex ossibus, dekoracje i napisy ułożone $\mathrm{z}$ kości ${ }^{64}$.

Zwyczaj budowania nietrwałych konstrukcji służących do eksponowania relikwii wiązał się ściśle ze wspominanymi już translacjami świętych z katakumb w Rzymie. Ich sprowadzaniu towarzyszyły wielkie uroczystości, których integralną częścią była procesja służąca powitaniu i wprowadzeniu szczątków świętych do ich nowego domu. Po niej często następował obrzęd wystawienia relikwii na specjalnie w tym celu wzniesionej trybunic. Widoki takich trybun, platform czy może po prostu scen translacyjnych (niem. Translationsbühne) wybudowanych w latach 1652 i 1752 zachowały się na obrazach w kościele klasztornym w Wettingen w Szwajcarii ${ }^{65}$. Szczególnie ciekawy jest rysunek piórkiem z r. 1674 zachowany w dokumentach Actio Salutationis relikwii św. Konstancjusza w szwajcarskim Rorschach [il. 4$]^{66}$. Ukazuje on wnętrze kościoła

${ }^{61}$ Przewodnik abo..., s. 77, 79.

${ }^{62}$ A. L e g n e r, Kölnische Hagiophilie. Die Domreligienschranke und ihre Nachfolgeschaft in Kölner Kirchen, „Kölner Domblatt”, 51, 1986, s. 195-274; Idem, Reliquien..., s. 154-171; S c h o m m e r s, dz. cyt, s. 201-220.

${ }^{63} \mathrm{Legner}$, Reliquien..., s. $199-219$.

${ }^{64} \mathrm{~S}$ c h o m m e r s, dz. cyt, s. 221-235, il. 112-116; L e g n e r, Kölner Heilige..., szczególnic s. 214-219.

${ }^{65}$ A c h e r m a n n, dz. cyt., s. 205, przyp. 338; B r o s e t t e, dz. cyt., s. 342.

${ }^{66}$ A c h e r m a n n, dz. cyt., s. 209 n., tabl. 14; B r o s e t t e, dz. cyt., Bd. 1, s. 348. 
$\mathrm{z}$ dekoracją scenograficzna, gdzie wyniesiony podest ujęty jest $\mathrm{z}$ boków kulisami z malowanymi makietami zabudowy miejskiej i flankowany przez wysunięte w stronę widzów bramy. W głębi wznosi się ołtarz, a za nim iluzjonistycznie malowane podwyższenie, na którym spoczywają relikwie męczennika, a jeszcze wyżej jego malowany wizerunek. Sądząc z opisu uroczystości po lewej stronie trybuny znajdowało się wejście do prezbiterium, po prawej zaś ambona i kredencja w kształcie stołu, które rysownik pominął.

W kontekście uroczystości w Krakowie warto opisać dwa inne przykłady dekoracji okolicznościowych. Szczególnie ciekawe wydają się uroczystości rocznicowe św. Liboriusza, obchodzone w katedrze w Paderborn w r. 1736 ${ }^{67}$. Wspominano wówczas przeniesienie relikwii patrona Westfalii z Le Mans w r. $836^{68}$. Uroczystościami kierował osobiście książę elektor Klemens August Wittelsbach, biskup Münster, Hildesheim i Osnabrück, wielki mistrz Zakonu Krzyżackiego. Na kapitule generalnej w dniu 14 sierpnia 1735 ustalono, że wielkie święto ku czci Liboriusza rozpocznie się w dniu 22 lipca roku następnego, w dzień patrona, diecezji i będzie trwało przez osiem dni. Biskup wystarał się u papieża o odpust dla wszystkich, którzy w ciagu trwania uroczystości nawiedzą katedrę i przyjmą Najświętszy Sakrament. Ponad tysiąc talarów wydano tylko na przystrojenie katedry. Przygotowano cztery bramy triumfalne, przez które przejść miała procesja w dniu otwierającym obchody. W sobotę 22 lipca 1736 r. około godziny trzeciej do Paderborn przyjechał biskup. Przedstawiciele możnych, duchowieństwa i plebsu powitali go obok chóru zachodniego katedry, potem wszyscy weszli do kościoła, gdzie hierarcha rozpoczał obchody intonując uroczyste nieszpory. Później biskupi sufragani i prałaci w uroczystej procesji wynieśli relikwiarz świętego Liboriusza i ustawili go w nawie głównej na przygotowanym specjalnie tronie. Później, aż do wieczora trwały kazania. Następnego dnia miał miejsce najważniejszy punkt programu, procesja $\mathrm{z}$ relikwiami św. Liboriusza. Biskup elektor niósł Najświętszy Sakrament pod baldachimem

${ }^{67}$ Szczegółowe opisy uroczystości zawarto w specjalnych drukach okolicznościowych wydanych po niemiecku i po łacinie: Beschreibung des Libori-Jubiläums in Paderborn 1736, Hildesheim, gedruckt bey Schlegels Erben (o. J.); Descriptio sancti triumphi, quem S. Liborio adornavit Clemens Augustus, Paderbornae 1737. Streszczenie opisów z w. XVIII znaleźć też można w: Geschichtliche Erinnerungen bei der Feier des tausendjähriger Jubelfestes, Paderborn 1836, s. 100-123; C. M e rt en s, Der Heilige Liborius. Sein Leben, seine Verehrung und seine Reliquien, Paderborn 1873, s. 134-140; F. S c h r ö d e r, Die Verehrung des hl. Liborius im Erzbistum Paderborn, [w:] Sankt Liborius sein Dom und sein Bistum. Zum 1100 jährigen Jubiläum der Reliquienübertragung, hrsg. von P. Simon, Paderborn 1936, s. 59-60.

${ }^{68} \mathrm{O}$ sw. Liboriuszu jako patronie archidiecezji Paderborn por.: A. C o h a u s z, St. Liborius aus Le Mans - Patron der Erzbistums Paderborn, [w:] Bistumspatrone in Deutschland, Hrsg. August Leidl, München-Zürich 1984, s. 192-198. 
trzymanym przez rycerzy zakonu niemieckiego ubranych $w$ białe płaszcze z czarnymi krzyżami. Relikwiarz świętego nieśli na zmianę biskupi sufragani, prałaci, opaci oraz przedstawiciele władzy świeckiej. Wszyscy uczestnicy procesji trzymali zapalone świece. Obok ratusza procesja przystanęła, aby wysłuchać kazania kaznodziei katedralnego ojca Gabriela Ericha, a biskup zajął na ten czas miejsce na podwyższeniu, które wzniesiono dla niego obok jednego z łuków triumfalnych. Procesje zakończył śpiew hymnu ambrozjańskiego. W ciagu kolejnych dni cześć świętemu oddawali przedstawiciele poszczególnych parafii, a studenci przygotowali przedstawienie teatralne ukazujące losy relikwii patrona miasta i diecezji. W dniu 26 lipca ksiazżę biskup ofiarował relikwiom św. Liboriusza wspaniałe dary, wśród których były dwa pięcioramienne świeczniki o wysokości pięciu stóp każdy, rzeźbiony stół oraz ramy do obrazu, wszystko wykonane $\mathrm{z}$ litego srebra. W dniu 28 lipca odbyła się uroczysta promocja doktorska pięciu kapłanów świeckich i pięciu jezuitów. Dzień później powołano bractwo Św. Liboriusza, a biskup zapisał się do niego jako pierwszy. Tego samego dnia wieczorem wszystkie ulice miasta zapłonęły iluminacjami. Ostatniego dnia oktawy, w uroczystej procesji zaniesiono relikwie patrona do kaplicy pod jego wezwaniem na górze Św. Liboriusza, gdzie zazwyczaj spoczywały. Gdy tylko biskup zakończył ostatnią modlitwę, rozległy się w kościołach wszystkie dzwony, a z dział ustawionych na umocnieniach wokół miasta oddano salwy. W ten sposób przed północą zakończyły się obchody jubileuszu. Według obliczeń $\mathrm{w}$ ciągu ośmiu dni w katedrze Komunię świętą przyjęło 20000 a w innych kościołach miasta 10000 wiernych. W ciagu tego samego czasu w katedrze odprawiono ponad 100 mszy. Na zakończenie wszystkich uroczystości odbył się wielki pokaz ogni sztucznych. Pośrodku sceny tego widowiska wznosił się wielki łuk triumfalny, na którym ukazano św. Liboriusza i Karola Wielkiego w zaprzęgu ciagnionym przez orła, lwa, feniksa i pawia. Po bokach tej grupy z jednej strony ukazano papieża Leona III (za czasów którego w r. 799 w miejscowej katedrze poświęcony został ołtarz), z drugiej zaś Ferdynanda Bawarskiego (za rządów którego relikwie św. Liboriusza zostały sprowadzone do miasta). $Z$ tyłu w ogrodach ustawione były makiety rezydencji paderborneńskiej i katedry. Na pierwszym planie ukazano personifikacje trzech bóstw toczących wodę, która zlewając się w jeden strumien symbolizowała łączność najważniejszych rzek Westfalii. Pokazy ogni obejmowały cały ogród i przeprowadzone zostały $\mathrm{z}$ wielką maestrią. Ich integralną częścią były ogniste piramidy $i$,nocne obrazy" wyczarowane $z$ ognia, ich dokładny opis wykracza już jednak poza ramy tego tekstu. Jak wspomniałem, najważniejszą częścią dekoracji przygotowanych z okazji uroczystości stał się ołtarz świąteczny, bogata konstrukcja ustawiona pośrodku nawy i dźwigająca relikwiarz św. Liboriusza. „Festaltar" zaprojektowany został przez nadwornego architekta biskupa Franza 
Christopha Nagela, a rzeźby z drewna złoconego w całości wykonali Johann Theodor Axer i Johann Philipp Pütt. Dzieło to znamy nie tylko z opisów, ale i $\mathrm{z}$ ryciny opublikowanej $\mathrm{w}$ wydawnictwie towarzyszącym uroczystościom [il. 5] $]^{69}$. Co więcej, najważniejsze elementy tej struktury zachowały się do naszych czasów, co jakiś czas są nawet składane i wykorzystywane na nowo w czasie uroczystości ku czci świętego patrona. Ów „Ehrengerüst” wyniesiony był na trzech stopniach i w swej środkowej części mieścił niską mensę w kształcie sarkofagu, na której cztery figurki aniołów podtrzymywały relikwiarz świętego. W narożach wznosiły się cztery wysokie postumenty, na których stały personifikacje Wiary, Nadziei, Kultu św. Liboriusza i Katedry w Paderborn. Całą konstrukcje nakrywał baldachim podwieszony u sklepienia kościoła, zdobny w cztery rozłożyste skrzydła podtrzymywane przez anioły o rozwianych szatach. Szczyt i narożna lambrekinu zdobily bogato rzeźbione lampiony.

Równie ciekawy przykład inscenizacji związanych z kultem świętych stanowi szwajcarskie opactwo w Säckingen, poświęcone św. Fridolinowi $i^{70}$. Głównym elementem procesji ku jego czci urządzanych tutaj corocznie po dziś dzień były ruchome trybuny, na których przebrani ludzie odgrywali zmieniające się sceny $\mathrm{z}$ historii świętego i jego męczeństwa. Adolf Reinle, który przebadał procesje odbywające się w latach 1730-1783, ustalit, że miały one rozbudowany, bardzo starannie opracowany program. Na czele pochodu szli zawsze dwaj otwierający (niem. "Wegemacher”), dalej zaś konno jechali muzykanci. Za nimi postępował archanioł Michał $\mathrm{z}$ mieczem i tarczą $\mathrm{w}$ towarzystwie dwóch innych aniołów. Ważny element stanowiła grupa około 50 zbrojnych pod dowództwem oficerów, podzielona w taki sposób, żeby po kilku z nich stanowiło obstawę relikwiarza i najważniejszych osób uczestniczących w procesji. Wokół żywych obrazów szli ludzie przebrani w błękitne szaty, dźwigający insygnia i tarcze herbowe. Cała ta część pochodu była zorganizowana na sposób typowy dla renesansowych trionfi. Druga część miała charakter rozbudowanego korowodu z ciałem zmarłego. Sześciu kapłanów w dalmatykach (w w. XVIII byli to zawsze kapucyni ze związanego $\mathrm{z}$ opactwem klasztoru w Laufenburgu) niosło sarkofag z relikwiami świętego, przed nimi zaś kroczyło trzech celebransów, sprawujących w tym dniu obrzędy liturgiczne. W omawianym okresie budowa-

${ }^{69}$ Beschreibung des Libori-Jubiläums...; Theatrum Sacrum. Der Libori-Festaltar von 1736, Erzbischöfliches Diözesanmuseum Paderborn, 26.07. - 8.09. 1986, Paderborn 1985; Liborius im Hochstift Paderborn. Seine Verehrung in Werken der Architektur und der bildenden Kunst. Eine Austellung der Erzdiözese Paderborn - veranstaltet vom Erzbischöflichen Diözesanmuseum 27. Juli bis 7. September 1986, Paderborn 1986, kat. 68, s. 144-147.

${ }^{70}$ A. R e in le, Die Säckinger Fridolinsprozession und ihre lebenden Bilder von 1730 bis 1783, „Zeitschrift für Schweizerische Archäologie und Kunstgeschichte”, 47, 1990, s. 305-326. 
no zawsze sześć trybun określanych jako fercula ${ }^{71}$. Były to zbite $\mathrm{z}$ desek solidne podstawy, które dźwigało na ramionach od dziesięciu do szesnastu ludzi. $\mathrm{Na}$ każdej z nich ustawiona była scena nazywana labarum ze względu na wiszącą tablicę, albo sztandar z nazwą ukazanego wydarzenia. Ten przydługi nieco passus prowadzi to stwierdzenia, że corocznie, przed i po procesji relikwie św. Fridolina przez jeden dzień spoczywały w kościele u wejścia do chóru na specjalnie w tym celu sporządzanej konstrukcji. Szczęśliwie, budowla taka przygotowana na uroczystości w r. 1782 zachowała się do naszych czasów [il. 6]. Jej fundatorem był kanonik Johann Michael Kessler stojący na czele bractwa św. Fridolina, praktykujący matematyk i inżynier. On też zaprojektował budowlę, określaną w źródłach jako „Expositorium”, „Gestell”, albo „Postament” ${ }^{\text {”2 }}$. Zbudowana $\mathrm{z}$ drewna, składa się ona $\mathrm{z}$ prostego podestu, na którym na wysokich cokołach stoją cztery kanelowane kolumny o złoconych głowicach kompozytowych. Podpory dźwigają masywne belkowanie to zaś solidną płytę, na której kładziony jest relikwiarz. Opisana konstrukcja jest dość późna i pochodzi z czasów gdy schyłkowy, zimny barok oraz rodzący się neoklasycyzm wypierały lekkie i kapryśne rokoko. Na tej masywnej, ciężkiej konstrukcji do dziś ustawia się jednak srebrny relikwiarz, który powstał dwadzieścia lat wcześniej w r. 1763. Jego lekka, ażurowa i jakby bezcielesna konstrukcja zamyka w sobie relikwie patrona opactwa. Jej zwieńczenie stanowi rzeźba ukazująca św. Fridolina prowadzącego za rękę szkielet. Trzeba bowiem pamiętać, że najsławniejszy cud iroszkockiego benedyktyna polegał na wskrzeszeniu $\mathrm{z}$ martwych możnowładcy o imieniu Ursus. Ów właściciel ziemski ofiarował świętobliwemu mnichowi część swoich włości pod budowę klasztoru w Säckingen, potwierdzając swą darowiznę w testamencie. Po śmierci jego brat Landolf zakwestionował donację, Fridolin - tak jak św. Stanisław - był więc zmuszony wskrzesić $\mathrm{z}$ martwych swego dobroczyńcę i zaprowadzić przed oblicze sądu ${ }^{73}$.

${ }^{71}$ Nazwa ta wywodziła się oczywiście od rzymskich ruchomych trybun używanych w czasie procesji religijnych do przenoszenia wizerunków bóstw; Reinle, dz. cyt., s. 308 . Warto dodać, że bodaj najsławniejsze fercula używane po dziś dzień zachowały się na Sycylii. Są to srebrny wóz św. Agaty przechowywany na co dzień w Muzeum Diecezjalnym przy katedrze w Catanii oraz paradne wozy przygotowywane z okazji procesji ku czci św. Róży w Palermo.

${ }^{72} \mathrm{R}$ e i $\mathrm{n} \mathrm{l}$ e, dz. cyt., s. 319 , il. 4 .

${ }^{73} \mathrm{R}$ e in 1 e, dz. cyt., s. 311 . Trzeba w tym miejsce przypomnieć, że od początku w. XX w literaturze naukowej trwa spór dotyczący interpretacji scen odkutych na kamiennej chrzcielnicy z pol. w. XII w szwedzkim Tryde. Badacze dopatruja sie w nich wydarzeń z życia św. Stanisława lub sw. Fridolina; por. polemiczne stanowiska w: J. S v a n b e r g, The Legend of Saint Stanislaus and King Boleslaus on the $12^{\text {th }}$ century Font in Tryde, Sweden, „Folia Historiae Artium, Seria Nowa" 5-6, 2001, s. 25-42; M. W a l c z a k, O chrzcielnicy w Tryde raz jeszcze. Uwagi na marginesie artykutu Jana Svanberga, The Legend of Saint Stanislaus and King Boleslaus on the $12^{\text {th }}$ century Font in Tryde, Sweden, „Folia Historiae Artium. Seria Nowa” 5-6 (2001), s. 25-42, „Folia Historiae Artium. Seria Nowa" 7 (2002), s. 107-111. 
Krakowski jubileusz w r. 1753 musiał mieć lokalne antecendencje. Jedną z najwcześniejszych znanych nam uroczystości religijnych na terenie Rzeczypospolitej, której nadano bogatą oprawę w formie architektury okazjonalnej było przeniesienie relikwii św. Kazimierza do nowej kaplicy przy katedrze w Wilnie w dniu 14 sierpnia $1636^{74}$. Jak pisał w swych pamiętnikach Albrycht Radziwiłł: „ceremonii ten był początek: wczora naprzód katafalk w pośrodku kościoła wystawiony i pięknie przybrany przed nieszporem ciało świętego wyniesione...,75. Katafalk ten wsparty był na ośmiu kolumnach, a ponad nim wznosił się wysoki łuk z mniejszymi kolumnami poprzedzielanymi niszami ${ }^{76}$. Bogatą oprawę artystyczną miały też coroczne uroczystości ku czci św. Wincentego, obchodzone w sposób szczególny przez nowicjuszy dominikańskich w Krakowie. Młodzież zakonna czciła świętego „w kolumnach ognistych, w rożnych Figurach, tryumfalnych Processyach", zaś relikwie jego ramienia wystawiane były „na srzodku Kośćioła w Feretrum" "77. Powszechnie znana i wielokrotnie opisywana była uroczystość przeniesienia relikwii św. św. Sykstusa i Krystyny z kościoła parafialnego do kościoła św. Barbary, którą w r. 1612 przygotowali krakowscy jezuici. W farze wzniesiono wówczas katafalk obity czerwonym adamaszkiem, a w świątyni przyjmującej po bokach ołtarza głównego zbudowano dwa theatra, ustawione pomiędzy ośmioma piramidami i nakryte baldachimami. Na ołtarzu głównym umieszczono malowidło pędzla Tomasza Dolabelli przedstawiające świętych, na theatrach zaś po uroczystej procesji wokół Rynku Głównego wystawiono przeniesione relikwie ${ }^{78}$. W dniu 17 lipca 1685 r. celebrowano w Krakowie uroczystość beatyfikacji Szymona z Lipnicy. Jego relikwie, które od czasu najazdu Szwedów w r. 1655 spoczywały w katedrze, złożono na bogatym katafalku w pobliżu ołtarza głównego, skąd po modlitwach i kazaniu zabrane zostały do macierzystego kościoła bernardynów. Tu także złożono je na bogato przystrojonym podeście ${ }^{99}$.

${ }^{74} \mathrm{Ch}$ rości ck i, Architektura okazjonalna..., s. 226, przyp. 33; ostatnio: V. D ol in $\mathrm{sk}$ a s, The Beginnings of the Treasury and how it fluorished. Traces of Mindaugas's Cathedral Treasury, [w:] Vilniaus Katedros Lobynas. Vilniaus Cathedral Treasury, ed. R. Budrys, V. Dolinskas, Vilnius 2002, s. 273-274.

${ }^{75}$ Pamiętniki Albrychta X. Radziwilla, kanclerza w. Litewskiego, wydał z rękopisu E. Raczyński, Poznań 1839, t. I, s. 322; A. S. R a d z i w i 1 1, Pamiętnik o dziejach w Polsce, t. 1: 1632-1636, przekład i opracowanie A. Przyboś, R. Żeleweski, Warszawa 1980, s. 555-556.

${ }_{76}$ T. C h y c z e w s k a-Hen n e l, Pobyt Maria Filonardiego w Wilnie (1636 r.), „Barok. Historia. Literatura. Sztuka", V/2, 10 (1998), s. 57-61, szczeg. s. 58.

${ }^{77}$ Kleynoty Stotecznego Miasta Krakowa..., s. 64.

${ }^{78} \mathrm{~J}$. W i e le w i c k i, Dziennik spraw domu zakonnego OO. Jezuitów u św. Barbary w Krakowie, t. 3: 1609-1619, Kraków 1889, s. 89; Z a ł ę s k i, dz. cyt., s. 76, przyp. 2; R o ż e k, Uroczystości..., s. 229; J. P a s z e n d a, Kościót Św. Barbary w Krakowie z domem zakonnym księży jezuitów. Historia i architektura (Biblioteka Krakowska, nr 125), Kraków 1985, s. 216.

${ }^{79}$ R o ż e k, Uroczystości..., s. 243; R. G us t a w, K. G rud zi í s k i, Błogosławiony Szymon z Lipnicy, Kalwaria Zebrzydowska 1988, s. 105. 
Ważnym źródłem opisanych zwyczajów i dekoracji mogły być rozpowszechniane przez Kościół potrydencki nabożeństwa eucharystyczne, w szczególności zaś nabożeństwo czterdziestogodzinne ${ }^{80}$. Ten typ nabożeństwa wykształcony w czasach nowożytnych polegał - by zacytować Stanisława Mossakowskiego - „na modlitewnej adoracji konsekrowanej Hostii wystawionej w kościele przez kolejnych czterdzieści godzin w symbolicznym nawiązaniu do takich faktów z historii biblijnej jak czterdzieści dni trwania potopu, czterdzieści lat wędrówki Żydów do Ziemi Obiecanej, czterdzieści dni, w czasie których Chrystus pościl modląc się na pustyni, czterdzieści godzin przebywania Jego ciała w grobie przed Zmartwychwstaniem, czy wreszcie czterdzieści dni trwania Wielkiego Postu" ${ }^{\prime \prime 1}$. Obchody zapoczątkowane w Mediolonie w latach trzydziestych XVI w. przeniesione zostały do Rzymu około połowy stulecia za sprawa Filipa Nereusza i zgromadzenia jezuitów. Od tego też czasu jezuici propagowali nabożeństwo poza granicami Italii, tak że w końcu stulecia było ono znane także w Polsce. W r. 1623 papież Urban VIII rozszerzył je na cały Kościół powszechny. Przepisy liturgiczne nakazywały gruntowne przygotowanie świątyni przed uroczystością, w tym zasłonięcie wszystkich obrazów o treści nieeucharystycznej oraz zdjęcie z ołtarza relikwii, tak aby nic nie odrywało wiernych od kontemplacji Najświętszego Sakramentu. Należy pamiętać, że od średniowiecza kult relikwii i kult Eucharystii rozwijały się paralelnie i łączyło je bardzo wiele podobieństw $^{82}$. Konstrukcja wawelskiego tronu św. Stanisława musiała też przypominać niektóre castra doloris ${ }^{83}$. Jego zasadnicze części składowe, a więc

${ }^{80} \mathrm{~W}$ języku polskim por. A. P o d l e ś, Dzieje czterdziestogodzinnego nabożeństwa w Polsce, [w:] Studia do dziejów liturgii w Polsce, t. 4, red. W. Schenk, Lublin 1982, s. 253-284; E. G i e y s z t o r-M i 1 o b ę d z k a, Nabożeństwo czterdziestogodzinne a sztuka, „Biuletyn Historii Sztuki”, XLVII, 1985, nr 1-2, s. 3-14; S. Mossakowski, Projekt „Teato di Quarantore” autorstwa Giovanniego Battisty Gisleniego”, „Biuletyn Historii Sztuki”, LXII, 2000, nr 1-2, s. 51-85, o historii nabożeństwa s. 52-55, 70 (tu też w przypisach 6, 7 i 9 zebrana pełna literatura zagadnienia).

${ }^{81}$ Mos s a k ow s ki, Projekt..., s. 53.

${ }^{82}$ G. J. S n o e k, Medieval Piety from Relics to Eucharist. A Process of Mutual Interactions (Studies in the History of Christain Thought, vol. LXIII, ed. H. A. Oberman), Leiden-New York-Köln 1995; w Polsce: M. W a lc z a k, Alter Christus. Studia nad obrazowaniem świętości w sztuce średniowiecznej na przykładzie św. Tomasza Becketa (Ars Vetus et Nova, t. V, red. W. Bałus), Kraków 2001, s. 255-260.

${ }^{83}$ Materiał porównawczy jest olbrzymi i często omawiany w literaturze przedmiotu. $\mathrm{Z}$ najważniejszych pozycji por. Chrościcki, Architektura okazjonalna..., s. 250-234; Tenze, Pompa junebris...; L. P o p e $1 \mathrm{k}$ a, Castrum doloris oder „Trauriger Schauplatz”: Untersuchungen zu Entstehung und Wesen ephemerer Architektur (Österreichische Akademie der Wissenschaften, Veröffentlichungen der Komission für Kunstgeschichte, Hg. H. Fillitz, Bd. 2), Wien 1994; z nowszych pozycji por. też Z. Żygulski jr., Castrum doloris czyli Zamek Boleściwy. O polskim obyczaju pogrzebowym na podstawie opracowania lwowskiego historyka sztuki Borysa Szengery, [w:] Jan III 
„opus artificiosum", „columnae" pokryte światłami, dekoracja w postaci orłów, herbów i insygniów godności biskupiej wskazują jednoznacznie, że projektant czerpał z klasycznego repertuaru funeralnej architektury okazjonalnej.

Tron ustawiony był w nawie głównej, tuż przed ołtarzem św. Stanisława. Trudno wątpić, że projektant uwzględnił położenie i rozmiary grobu patrona Rzeczypospolitej, czyniąc z obydwu budowli scenograficzną całość. Tron musiał być dużo mniejszy, tak więc struktura cyborium ze złoconą kopuła, srebrną trumną i zespołem figur świętych patronów stanowiła dla niego naturalne tło. Był on najpewniej rodzajem rozbudowanego katafalku, gdzie pośrodku na kilku stopniach obitych tkaninami wznosił się podest dla relikwii. Otaczały go legendarne orły, które strzegły szczątków świętego i trzymały w szponach insygnia jego godności. Wystarczy przypomnieć, że ptaki te dźwigały srebrną trumnę świętego $\mathrm{z}$ daru królowej Elżbiety Lokietkówny, która była poprzedniczką trumny ufundowanej w r. 1633 przez Zygmunta III Wazę ${ }^{84}$. Zapewne pod jej wpływem orły podtrzymują także relikwiarz ramienia świętego, ufundowany do kościoła katedralnego przez Tomasza Zamojskiego w r. $1631^{85}$, oraz relikwiarz z daru biskupa Marcina Szyszkowskiego, ofiarowany przez niego do bazyliki św. Franciszka w Asyżu pomiędzy r. 1616 a $1621^{86}$. Bezpośrednim wzorem mogły być także cztery alabastrowe orły dłuta Jana Jerzego Lehnera, strzegące

Sobieski. Castrum doloris 1696-1996, Radom 1996, s. 31-37 oraz różnorodny materiał zebrany w: Przeraźliwe echo trąby żałosnej do wieczności wzywajacej. Śmierć w kulturze dawnej Polski od średniowiecza do końca XVIII wieku. Katalog wystawy pod kierunkiem i redakcja P. Mrozowskiego, 15 grudnia 2000-15 marca 2001, Zamek Królewski w Warszawie, Warszawa 2000.

${ }^{84}$ Por. wyżej, przyp. 46; o przebudowie ołtarza św. Stanisława i fundacji kolejnych trumien: M. Rożek, Katedra wawelska w XVII wieku (Biblioteka Krakowska, 121), Kraków 1980, s. 68-110 . K o c h a now s k a - R e i c h e, Najstarsze cykle narracyjne..., s. 37-38, właśnie na podstawie obecności orłów datuje powstanie trumny na czasy po koronacji Władysława Łokietka. Autorka ta przypisuje fundację temu właśnie władcy, co w świetle przytoczonych powyżej argumentów należy oczywiście odrzucić.

${ }^{85}$ Katalog zabytków sztuki w Polsce, t. IV: Miasto Kraków, cz. 1: Wawel, red. J. Szablowski, Warszawa 1965, s. 117; A. B u j a k, Patron. 750. rocznica kanonizacji sw. Stanisława, tekst K. J. Czyżewski, Kraków 2003, s. 129.

${ }^{86}$ Relikwiarz asyski wzmiankowany był w kilku zaledwie drukach o charakterze dewocyjnym, pozbawionych większej wartości naukowej; W. W e h r, Kaplica św. Stanistawa w Asyżu, „Duszpasterz Polski Zagranica” 4/3, 1953, s. 268; W 700-letniq rocznice kanonizacji św. Stanistawa (broszura wydana w Asyżu w r. 1953); S. B el c h, Święty Stanistaw biskup-męczennik, patron Polaków, Londyn 1976, s. 29. Z ważnych publikacji zagranicznych wymienić trzeba: B. Kleinschmidt, Die Basilika San Francesco in Assisi Bd. 1, Berlin 1915, s. 279; U G n ol i, Il Tesoro di San Francesco d'Assisi, Dedalo 1922, s. 435; E. Z o c c a, Assisi, Roma 1936, s. 136 (Ministero della Educazione Nazionale, Catalogo delle cose d'Arte e di Antichità d'Italia); Il tesoro della Basilica di San Francesco ad Assisi, Assisi-Firenze 1980, s. 112-113, nr 39, tabl. CXXIII, il. 37. Ostatnio został omówiony szczegółowo w: W a l c z a k, Kanonizacja św. Stanisława..., dz. cyt. 
ołtarza św. Stanisława w kościele na Skałce, który wzniesiony został w latach 1745-1746, według tradycji w pobliżu miejsca męczeństwa ${ }^{87}$. W jego zwieńczeniu znajdują się przedstawienia aniołów trzymających insygnia biskupie. Orły strzegące tronu w r. 1753 ustawione były parami, dwa stojace na szczycie strzegły relikwiarza, dwa ustawione zapewne o stopień niżej trzymały infułę i pastorał. Cała ta konstrukcja nakryta była baldachimem, który jak można się domyślać, podwieszony był u sklepienia katedry. Tworzył go zapewne dekoracyjny lambrekin i cztery skrzydła rozchodzące się na boki, tak jak w ołtarzu św. Liboriusza w Paderborn. W czterech narożach, w pewnej odległości od stopni stały elementy, które w opisach z r. 1753 nazwano "columnae”. Niestety w źródłach nowożytnych z terenów dawnej Rzeczypospolitej określenie to występuje w bardzo różnych znaczeniach. Tak więc „columna” równie dobrze może oznaczać kolumnę, filar i obelisk ${ }^{88}$. Wzmiankowane „columnae” $\mathrm{z}$ cała pewnością niczego nie dźwigały, nie pełniły więc funkcji podpór. W dekoracjach pogrzebowych z w. XVII i XVIII w narożach katafalków wprowadzano najczęściej wolnostojące obeliski i właśnie ich użycie wydaje się najbardziej prawdopodobne [il. 7$]^{89}$. Podobnie było przecież w czasie uroczystości z r. 1612, gdzie po bokach „teatrów” w kościele św. Barbary stały „piramidy” ${ }^{\circ}$. Można ponadto wskazać istotną analogię z terenu Krakowa. W latach 1683-1684 z fundacji biskupa Jakuba Zadzika powstało kamienne obramienie sadzawki obok kościoła na Skałce, w miejscu gdzie według legendy wyłowiono rybę z palcem św. Stanisława $\mathrm{w}$ brzuchu ${ }^{91}$. W jej narożnikach ustawiono cztery kamienne obeliski, odkute w r. 1690 przez Jacka Napora z Pińczowa i zwieńczone kamiennymi

${ }^{87}$ Katalog zabytków sztuki w Polsce, t. IV: Kraków, cz. V: Kazimierz i Stradom kościoły $i$ klasztory, 2, red. I. Rejduch-Samkowa, J. Samek, s. 8, il. 108; K. B r z e z i n a, Dekoracja rzeźbiarska Jana Jerzego Lehnera w kościele paulinów na Skałce w Krakowie, „Studia Claromontana", 17, 1997, s. 628 , przyp. 14, il. 36. Ważne uwagi na temat usytuowania wspomnianego oftarza sformulowal ostatnio Ś. L e n a r t o w i c z, Barokowy kościót na Skałce, historia powstania i geneza formy, „Peregrinus Cracoviensis” 14 (2003), s. 157-158.

${ }^{88}$ Stownik taciny średniowiecznej w Polsce, t. II, z. 4 (12), Wrocław-Warszawa-Kraków 1961, szp. 622-623; J. S o n d e 1, Stownik łacińsko-polski dla prawników i historyków, Kraków 1997, s. 171; Stownik polszczyzny XVI wieku, t. X, Wrocław-Warszawa-Kraków-Gdańsk 1976, s. 476.

${ }^{89}$ Por. np. castrum doloris Innocentego XII wzniesione w Rzymie w bazylice św. Piotra na Watykanie w r. 1700 wg projektu Giovanniego Battisty Continiego; Popelka, s. 125, il. 109; M. F a g i o lo, Il trionfo sulla morte. I catafalchi dei papi e dei sovrani [w:] La Festa a Roma dal Rinascimento al. 1870, Atlante, a cura di M. Fagiolo, Torino, Roma 1997, il. 32, tu także inne liczne przykłady.

${ }^{90}$ Por. wyżej, s. 247.

${ }^{91}$ Katalog zabytków sztuki w Polsce..., t. IV, dz. cyt., s. 26-27, il. 43, 44; M. K r a s n owo ls k a, I. K m i e t ow i c z-D r a th ow a, Krakowska Skatka: topografia i zabudowa, "Studia Claromentana" 17 (1997), s. 257-261. 
wizerunkami orłów trzymających $\mathrm{w}$ dziobach części ciała poćwiartowanego biskupa. We wnętrzu katedry znalazły się jeszcze dwa obeliski ustawione po bokach ołtarza św. Stanisława. Ich zadaniem było zapewne integralne połączenie konstrukcji tronu z architektura konfesji. Na wszystkich „columnae" zamontowane były świeczniki, zgodnie z ówczesnymi zwyczajami piętrowo, jedne nad drugimi.

Zastanawiając się nad charakterem stylowym dekoracji nie sposób pominąc faktu, że stanowiła ona dopełnienie nowej aranżacji katedry, projektowanej stopniowo przez Franciszka Placidiego. Architekt ten pracował dla kościoła katedralnego od r. 1743, kiedy to zatrudniono go do budowy kaplicy Lipskich i można postawić hipotezę, że to on był projektantem dekoracji okolicznościowych i architektury okazjonalnej ${ }^{92}$. Jeśli tak, to można domyślać się, że miała ona charakter monumentalny, a konstrukcja dominowała w niej wyraźnie nad dekoracją. Jak pisał Józef Lepiarczyk, Placidi był ,architektem pur sang", wyczulonym szczególnie na kwestie formy i bryły ${ }^{93}$. Jako świetny urbanista i znawca rozwiązań prespektywicznych, potrafiłby on sobie poradzić doskonale $\mathrm{z}$ wpisaniem struktury tronu we wnętrze katedry. Na pewno też wykorzystałby w pełni możliwości, jakie dawało ustawienie jej na tle konfesji św. Stanisława. Jeśli pod określeniem "columnae" kryły się obeliski, to wspierały się one na wysokich cokołach, a u nasady zaopatrzone były w głębokie podcięcia, tak jak w ołtarzu w kaplicy Doktorów przy katedrze krakowskiej ${ }^{94}$. Jak wyglądały dekoracje, trudno powiedzieć, choć kartusze $z$ herbami świętego były najpewniej płaskimi tarczami, które ujęto w ślimacznice i uzupełniono muszlami lub dekoracjami kwiatowymi. Jest bardzo prawdopodobne, że pojawiły się tam także ornamenty rocaille ${ }^{95}$.

Trudno wypowiadać się na temat symboliki budowli, której wygląd trzeba odtwarzać w wyobraźni. Można jednak zaryzykować kilka hipotez. Po pierwsze użycie dużej ilości świeczników - to jeszcze jeden element łączący strukturę tronu $\mathrm{z}$ ówczesnymi castra doloris. Tak jak one, budowla pomyślana była zapewne jako „piramida świateł” i symbolizowała nieśmiertelność duszy oraz jej wyniesienie do nieba ${ }^{96}$. Obeliski, jak powszechnie wiadomo, w pismach teoretyków z w. XVI i XVII uważano za budowle poświęcone słońcu i interpretowano jako symbol przejścia od sfery ziemskiej do niebiańskiej, odwiecznego

${ }^{92}$ J. L e p i a r c z y k, Architekt Franciszek Placidi okoto 1710-1782, „Rocznik Krakowski”, 37, 1965, s. 83, 114, 119; L e p i a r c zy k, P r z y b y s zew s k i, dz. cyt., s. 24-29.

${ }^{93}$ L e p i a r c zy k, dz. cyt., s. 117.

${ }^{94} \mathrm{~L}$ e p i a r c z y k, dz. cyt., il. 57.

${ }^{95}$ Wzorem służý może ponownie ołtarz w kaplicy Doktorów.

${ }^{96}$ P o p e 1 k an dz. cyt., s. 26-29, 34, 68; M o s s a k o w s k i, dz. cyt., s. 64, 69, przyp. 109. 
poszukiwana „sacrum"97. W architekturze Rzymu czasów Sykstusa V (1586-1589) dokonała się ich chrystianizacja, a autentyczne egipskie zabytki zostały ustawione w kluczowych punktach miasta, głosząc prawdę o Chrystusie prawdziwym słońcu oraz podkreślając autorytet następców św. Piotra ${ }^{98} . Z$ podobnych przesłanek wyrastała interpretacja obelisku jako symbolu świeckiej potęgi i chwały. Oznaczał on promieniowanie władzy, od której tak jak od promieni słońca zależało dobro ogółu. Właśnie jako pomnik chwały występował on często $w$ propagandzie artystycznej epoki Wazów ${ }^{99}$. W triumfainy sposób można by też wythumaczyć obecność obelisków w dekoracji katedry krakowskiej na uroczystości św. Stanisława ${ }^{100}$. Biskup i męczennik był przecież uważany za wielkiego dobrodzieja Rzeczypospolitej, sprawcę jej przewag militarnych, a miejsce na skrzyżowaniu naw od w. XIV pełniło funkcję trofealną ${ }^{101}$. Triumfalny aspekt patronatu świętego nad krakowską katedrą podkreślał wyraźnie już Jan Długosz pisząc, że: „pośród wszystkich katedr Kościoła Polskiego ona jedyna jest uwieńczona jak laurem krwią swego najświętszego biskupa św. Stanisława. Jedyna ma działającego cuda najświętszego zwierzchnika, pochodzącego z polskiego rodu, bardzo wytrwałego i zwycięskiego obrońce wiary i religii chrześcijańskiej, jedyna została uznana za godną tego zaszczytu"102. Niestety, kolorystyka budowli i dekoracji nie da się w żaden sposób odtworzyć. Można się jednak domyślać, że triumfalny aspekt jubileuszu przypominało też obfite użycie złota, czerwień zaś symbolizowała męczeńską śmierć świętego.

Przytoczone powyżej argumenty i zebrany materiał porównawczy kusza, aby dokonać hipotetycznej rekonstrukcji dekoracji okolicznościowych z r. 1753 [il. 8] $]^{103}$. Dodatkową zachętę stanowią publikacje historyków sztuki, którzy do

${ }^{97}$ W. S. Heckscher, Bernini's Elephant and Obelisk, "The Art Bulletin”, 29, 1947, s. 178; M o s s a k ow s k i, Projekt..., s. 64.

${ }_{98}$ J. M i z i o ł e k, Obeliski Rzymu i Krakowa w 2 potowie XVI w., „Barok. Historia. Literatura. Sztuka" 1-2 (1994), s. 153-159; M o s s a k o w s k i, Projekt..., s. 67-68.

${ }^{99}$ Por. m. in. J. C h rośc i c k i, Sztuka i polityka. Funkcje propagandowe sztuki w epoce Wazów 1587-1668, Warszawa 1983, s. 55-56; M. S t a h r, Medale Wazów w Polsce 1587-1668, Wrocław, Warszawa, Kraków 1990, s. 106-110; J. P o k o r a, Wazowskie enigmata: wieńne Zygmunta $i$ obeliski Władystawa oraz kłódka Jana Kazimierza, „Biuletyn Historii Sztuki”, LXV, 2003, nr 1, s. 7-40.

${ }^{100}$ Por. uwagi o triumfalnej wymowie zamków boleści: P o p e $1 \mathrm{k}$ a, dz. cyt., s. 84-88.

${ }^{101} \mathrm{Na}$ ten temat m.in.: Roże k, Ara Patriae..., s. 433-460; M. W a l c z a k, K. C z y ż e w s ki, Die Krakauer Kathedrale und die Marienkirche in ihrer Funktion für Hof und Stadt [w:] Krakau, Prag und Wien. Funktionen von Metropolen im frühmodernen Staat, Hrsg. M. Dmitrieva, K. Lambrecht, Stattgart 2000, s. 103-111.

102 Joannis Dlugossi senioris canonicis cracoviensis opera omnia, cura Alexandri Przezdziecki edita, vol. 7, Kraków 1863, s. 4; thumaczenie polskie w: Polska Jana Dlugosza, red. H. Samsonowicz, Warszawa 1984, s. 42.

${ }^{103}$ Komputerową wizualizację tronu św. Stanisława wykonała Joanna Betlej, za co winien Jej jestem wielką wdzięezność. 
takich rekonstrukcji się uciekają. Pionierem metody wykorzystującej do tych celów grafikę komputerową jest w Polsce Andrzej Betlej. W swojej książce o Pawle Giżyckim opublikował on imaginacyjne wizerunki niezachowanej architektury okazjonalnej, projektowanej przez tego jezuickiego architekta ${ }^{104}$. W przypadku dekoracji w katedrze krakowskiej opisy nie są zbyt szczegółowe, trudno więc mówić o rekonstrukcji sensu stricto. Prezentowana fotografia jest raczej „wizją" architektury okazjonalnej powstałej w r. 1753. Żywię jednak głębokie przekonanie, że takie działania mają swoje głębokie uzasadnienie metodologiczne ${ }^{105}$.

Obchody jubileuszu 750-rocznicy kanonizacji św. Stanisława przypadły na początek w. XXI. Zmieniły się sposoby świętowania. Dziś nie urządza się już procesji przy huku armat, nie buduje bram triumfalnych, nie zatrudnia świetnych artystów do zdobienia kościołów. Mimo to warto przekazać potomnym, w jaki sposób czczono kolejny z jubileuszów najważniejszego patrona diecezji krakowskiej. Warto zadbać, aby kolejne pokolenia historyków miały czym sycić swoją wyobraźnię. Rocznica stanisławowska powinna doczekać się pełnej dokumentacji faktograficznej ${ }^{106}$. Pozwolę sobie zakończyć swój tekst postulatem. Przygotujmy księge pamiątkową uroczystości stanisławowskich w r. 2003 !

\section{Ceremony of the Five-Hundredth Anniversary of Canonisation of St Stanislaus in Cracow in $\mathbf{1 7 5 3}$ in the Eyes of an Art Historian Summary}

On September 8, 1753 a celebration took place in the Wawel Cathedral to commemorate the five-hundredth anniversary of the canonisation of St. Stanislaus. The main element of a specially prepared decoration was a structure of considerable size as-

${ }^{104}$ A. B e 1 l e j, ,Sprawy pogrzebowe księcia Pawta Karola Sanguszki”. Przyczynek do badań nad sztukq funeralnq w Polsce w 2. połowie XVIII wieku, [w:] Sztuka Kresów Wschodnich, t. 4, red. A. Betlej, P. Krasny, Kraków 1999, s. 61-68, il. 1; Idem, Paweł Gizycki SI architekt polski XVIII wieku, Kraków 2003, il. 16, 17, 59, 60, 61.

${ }^{105} \mathrm{O}$ korzyściach płynących $\mathrm{z}$ analizy nie zachowanych dziel sztuki por. np. J. C h ro ś c i c k i, Architektura okazjonalna..., s. 216; Idem, Wiadomości o mecenacie artystycznym magnaterii i szlachty polskiej na podstawie panegiryków pogrzebowych od XVI do końca XVIII wieku, „Rocznik Historii Sztuki”, 9, 1973, s. 147-176.

${ }^{106}$ Za wzór mogą tu służyć wydawnictwa diecezji niemieckich, przykładowo Augsburga: Das große Ulrichslob. Erinnerung und Vermächtnis, herausgegeben von der Diözese Augsburg, Augsburg 1974; P. Rummel (Hg.), 1000 Jahre Sankt Ulrich 993-1993. Die Dokumentation, Augsburg 1994. 
sembled in the middle of the nave, opposite the martyr's tomb. It served as a throne on top of which a late Gothic reliquary, made by a Cracovian goldsmith Marcin Marciniec, for Stanislaus' head was placed. The structure was embellished with the Saint's coats of arms and candelabras and over it a canopy with wings spread to the sides was hung. On both sides of the reliquary two eagles were placed. Two more, holding a mitre and a crosier, stood underneath. In the four corners of the structure four obelisks adorned with candelabras were placed, while the sides of the altar of St. Stanislaus had two more with lights and bishop's insignia painted on them. Among various forms of relics veneration propagated by the Church after the Council of Trent, one was their solemn presentation to the congregation. The article analyses different examples of decorations connected with such presentations. As a close analogy to Cracow's celebrations a jubilee of the nine-hundredth anniversary of the translation of St. Liborius from Le Mans to Paderborn celebrated in 1736 was chosen. The analysis includes annual celebrations in honour of St. Florian at Säckingen and customs connected with the translations of relics from the catacombs in Rome to churches in the Habsburg countries. The examples listed and the analysis of the written sources about Cracow allowed a hypothetical reconstruction of occasional architecture and an interpretation of its symbolic contents. 


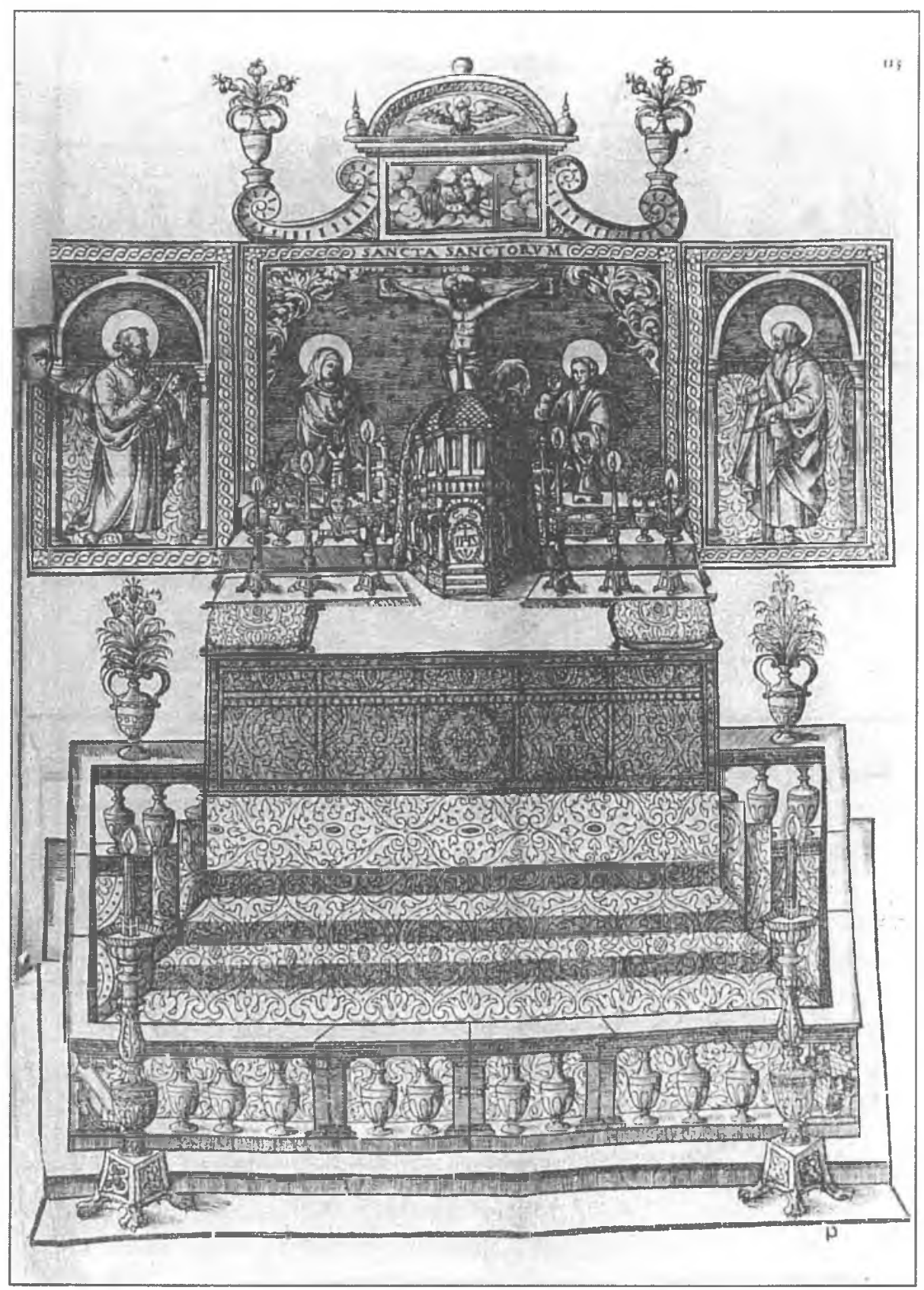

1. Jakob Müller, Kirchen Geschmuck, Monachium 1591, s. 113: Der festlich bereitete Altar; wg Schmommers. 


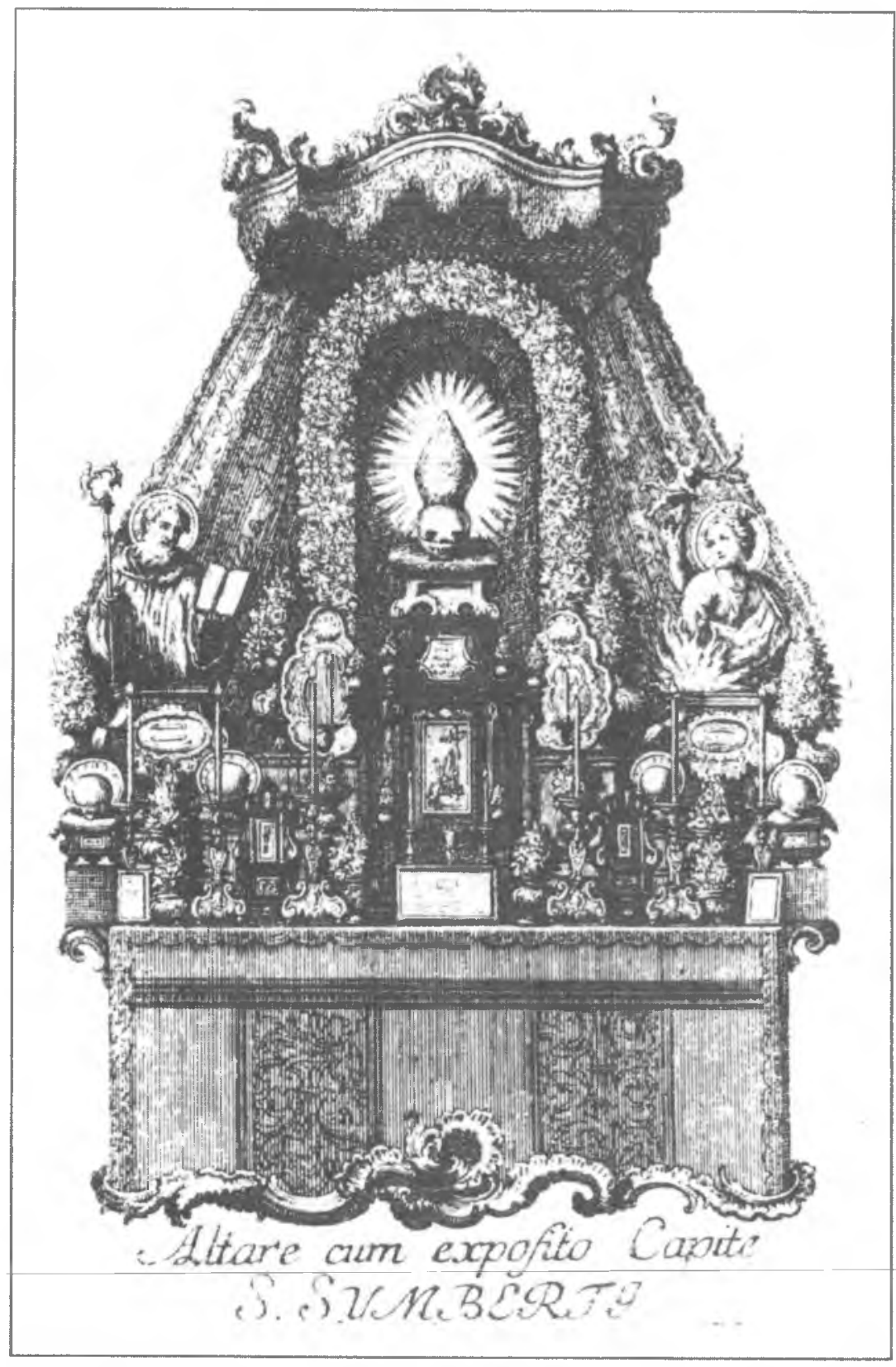

2. Geschichte von dem Leben [...] Bischofs Simpert, karta tytułowa, Augsburg 1792. 


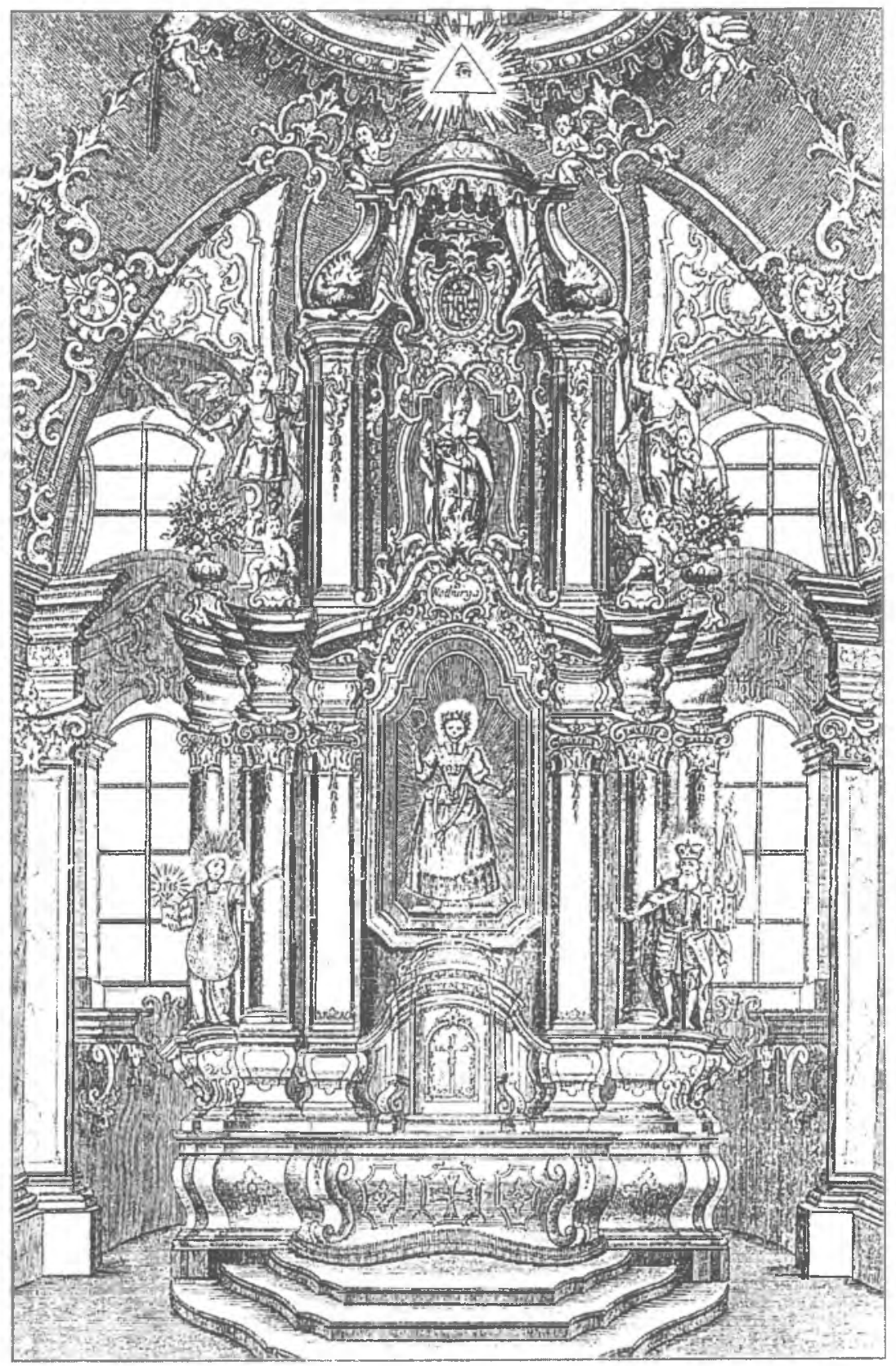

3. Eben, kościół parafialny, ołtarz św. Notburgi; ryc. F. X. Jungwirth, 1753; wg J. Periero, Acta Sanctae Notburgae, Antwerpia 1753. 


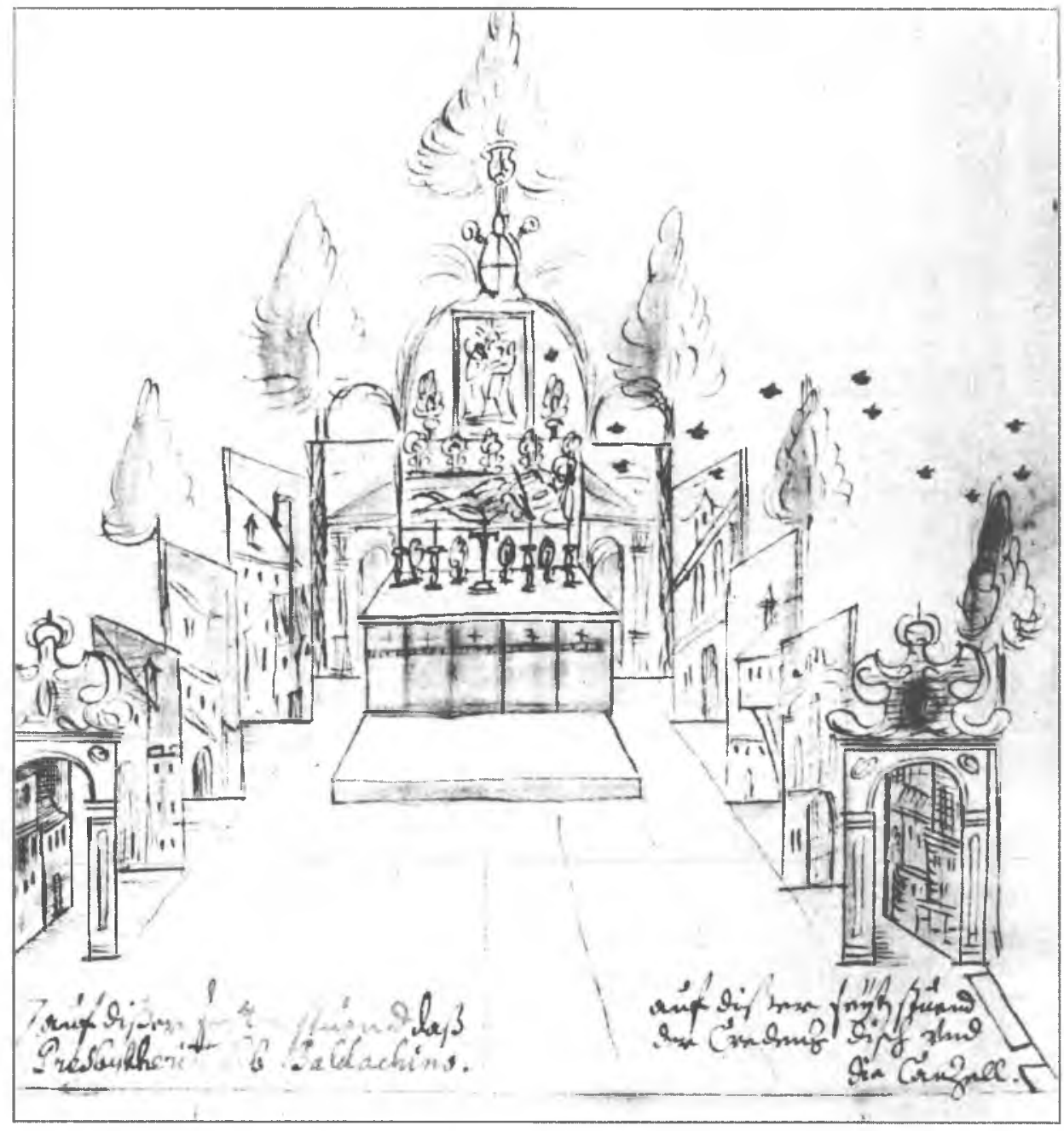

4. Rorschach, dekoracja okolicznościowa z okazji sprowadzenia z Rzymu relikwii św. Konstancjusza, 1674, rysunek piórkiem w rękopisie Miscellanea Comoediarum, Stiftsbibliothek, Sankt Gallen, Codex 1375; wg Achermann, dz. cyt. 


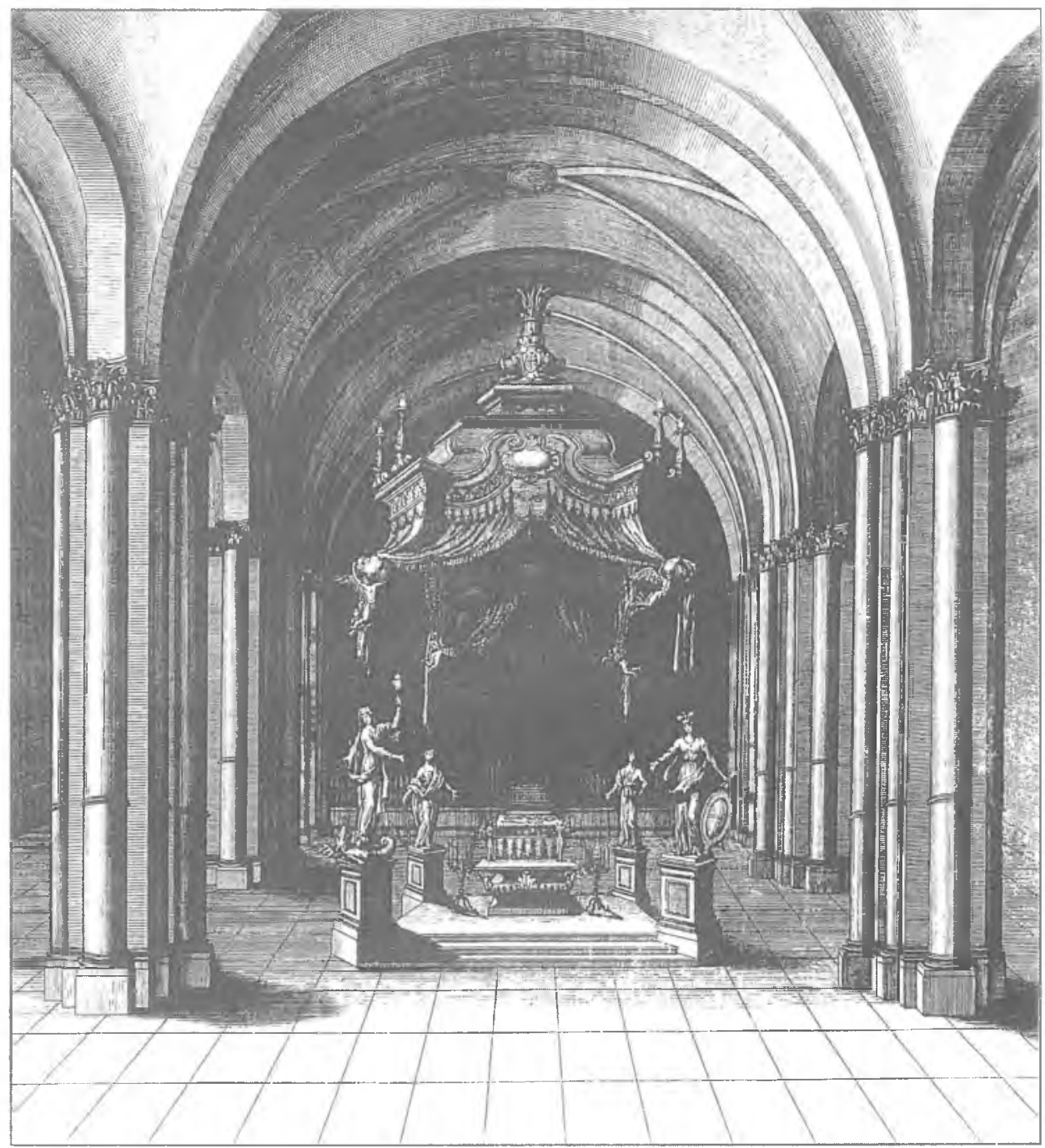

5. Paderborn, katedra, oltarz św. Liboriusza w czasie uroczystości rocznicowych w r. 1736; ryc. J. A. Pfeffel; wg Beschreibung des Libori-Jubiläums in Paderborn 1736, Hildesheim, gedruckt bey Schlegels Erben (o. J.). 


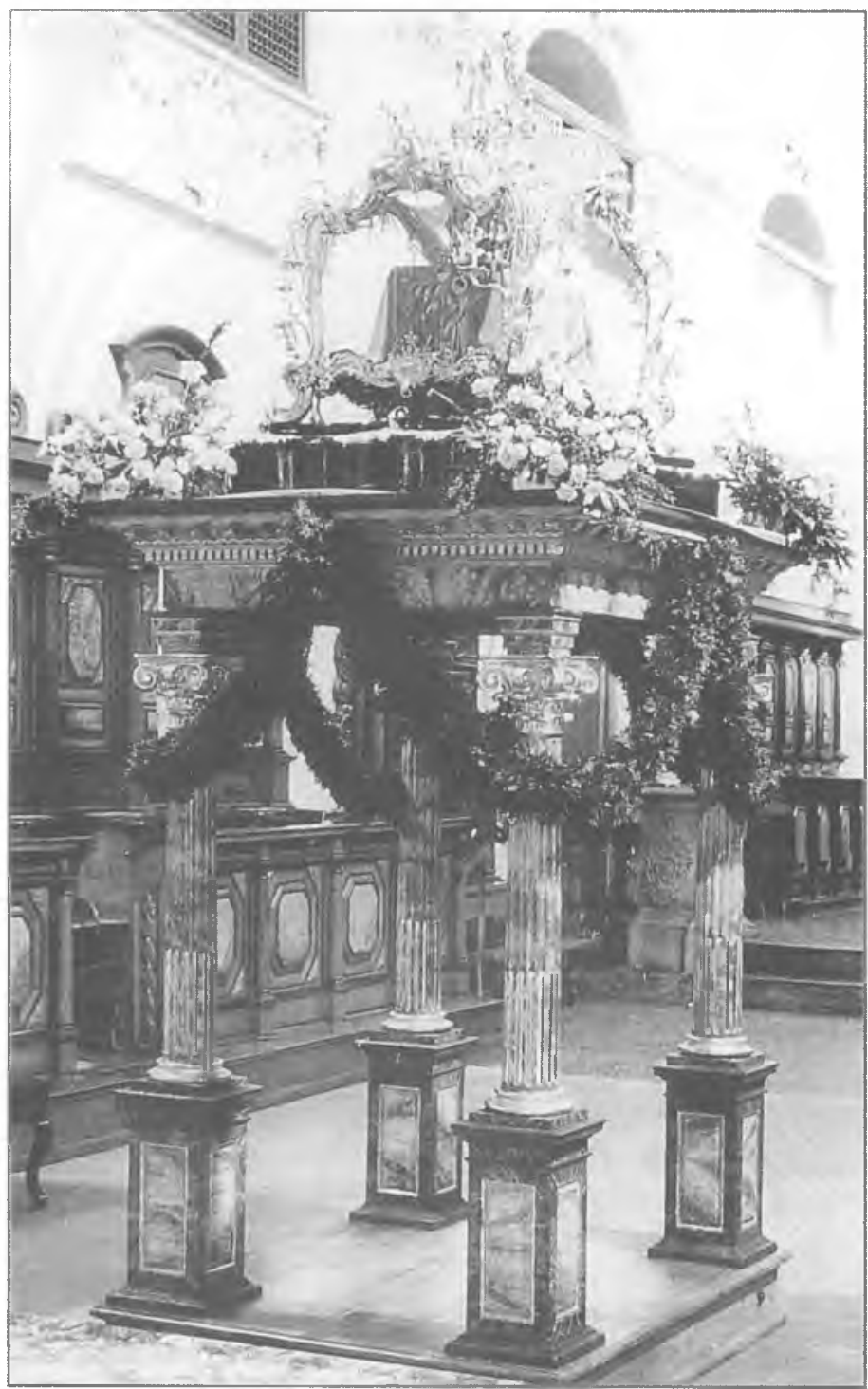

6. Säckingen, opactwo św. Fridolina, tron na relikwiarz św. Fridolina, 1782 r., wg Reinle, dz. cyt. 


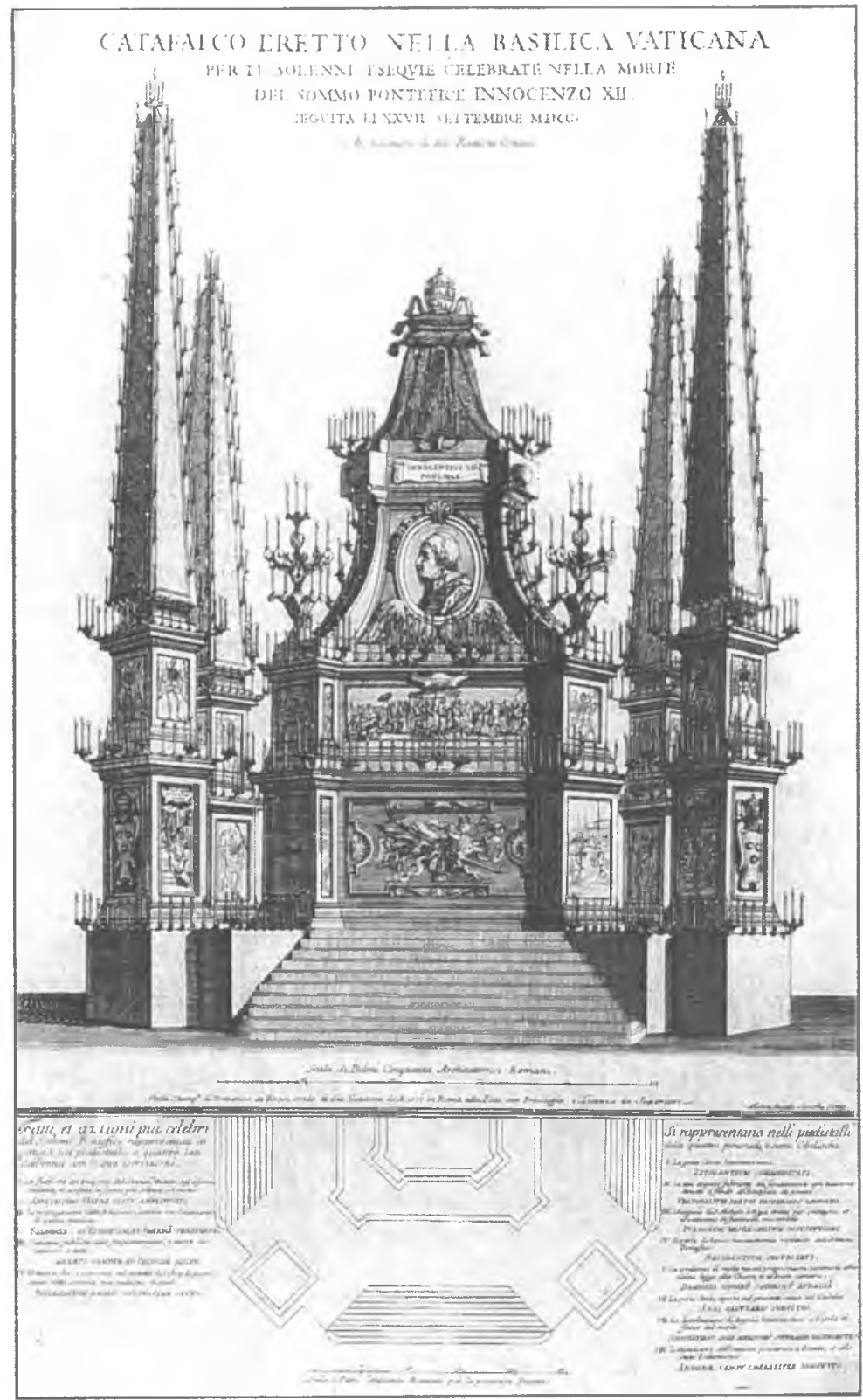

7. Castrum Doloris Innocentego XII wzniesione w Rzymie w bazylice św. Piotra na Watykanie wg projektu Giovanniego Battisty Continiego, 1700 r., Popelka, dz. cyt. 


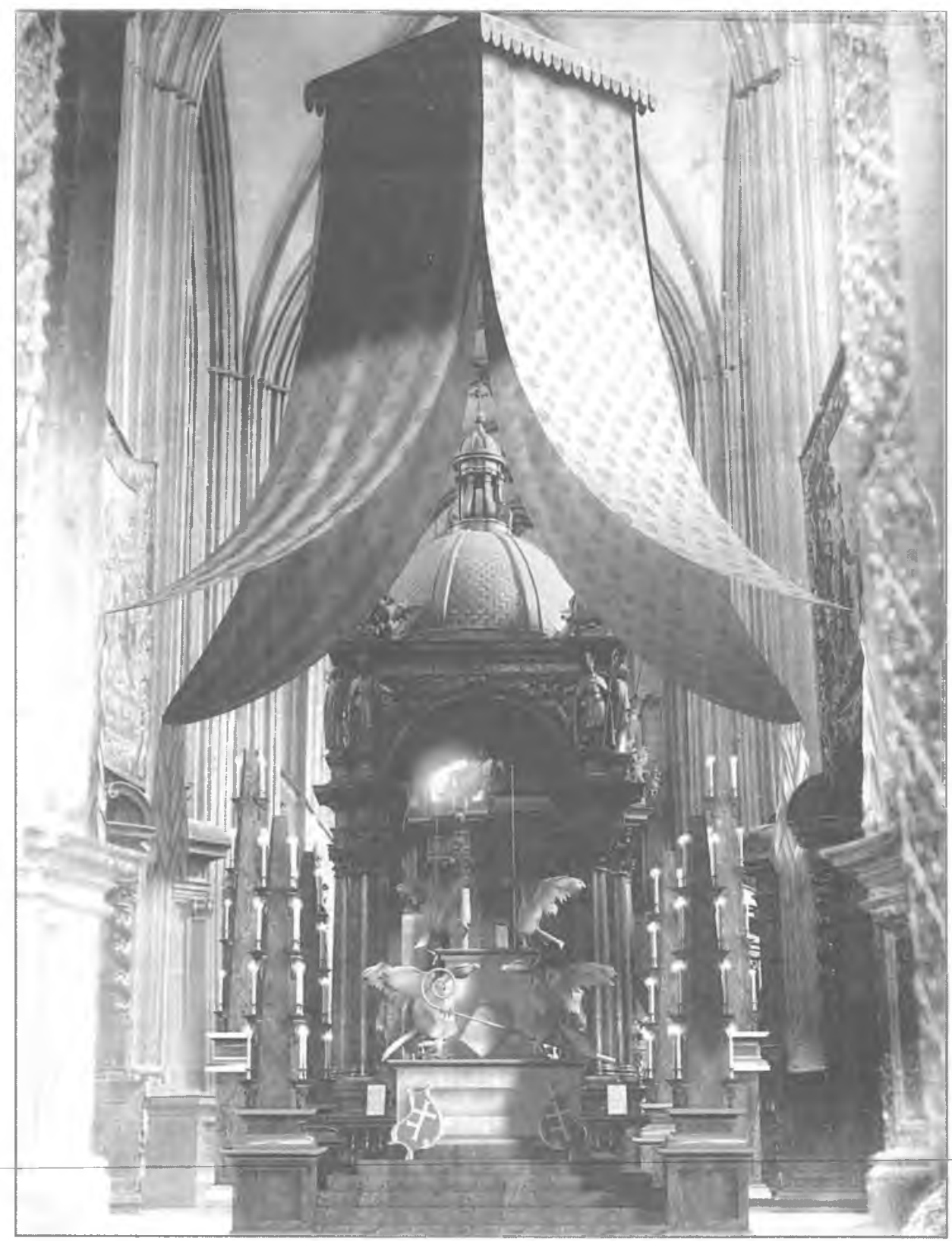

8. Tron na relikwiarz św. Stanisława, hipotetyczna rekonstrukcja architektury okazjonalnej w katedrze krakowskiej w r. 1753; opr. I. Betlej. 